\title{
A phytosociological classification of the Nylsvley Nature Reserve
}

\author{
B. J. COETZEE*, F. VAN DER MEULEN*, S. ZWANZIGER*, P. GONSALVES* AND P. J. WEISSER*
}

\begin{abstract}
The vegetation of the Nylsvley Nature Reserve in the Transvaal Mixed Bushveld is classified hierarchically by the Braun-Blanquet Method of vegetation survey. The vegetation is seasonal grassland and deciduous savanna with four floristically distinct major groups of plant communities: (1) grasslands and broad-leaved savannas on non calcareous sandy soils on elevated sandstone and felsite areas; (2) microphyllous thorn savannas on calcareous, clayey, bottomland alluvial soils and termitaria thickets; (3) grassland and thorn savanna on calcareous self-mulching vertic soils; and (4) secondary communities on long abandoned native settlements and recently ploughed land.

Seven primary communities with 12 community variations and 4 subvariations, and three secondary communities are described on the basis of 216 relevés. The survey was carried out at two levels of detail, an ecosystem study area in the broad-leaved savanna being surveyed in more detail, floristically and structurally, than the rest of the Reserve.

Résumé

UNE CLASSIFICATION PHYTOSOCIOLOGIQUE DE LA RESERVE NATURELLE DE NYLSVLEY

Une classification hiérarchique de la végétattion de la Réserve naturelle de Nylsvley dans le "Bushveld" Mixte du Transvaal a été obtenue au moyen d'un relevé exécuté suivant la mérhode de Braun-Blanquet. La végétation est faite de prairies saisonnières et de savane perdant ses festilles l'hiver avec quatre groupes majeurs floristiquement distincts de communautés de plantes:

1) des prairies et des savanes à larges feuilles sur des sols sablonneux non calcareux sur sites de grès et felsites;

2) des savannes épineuses microphylles sur des sols calcareux, argileux, au sous-sol alluvionnaire et les bosquets de termitières;

3) des prairies et une savane épineuse sur des sols vertics calcareux où l'herbe sèche recouvre le sol d'elle même (self mulching);

4) des communautés secondaires sur des emplacements que des populations indigènes ont abandonnés depuis longtemps et qui ont été labourés récemment.

Sept communautés primaires avec 12 variations de communautés et quatre sous-variations ainsi que trois communautés secondaires sont décrites sur la base de 216 relevés. L'inspection fut menée a deux niveaux de détails, une région destinée à l'étude de l'écosystème dans la savane à larges feuilles ayant été examinée de plus prés au point de vue floristique et structurel que dans le reste de le Réserve.
\end{abstract}

\section{CONTENTS}

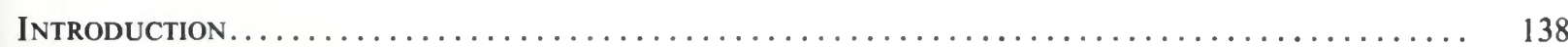

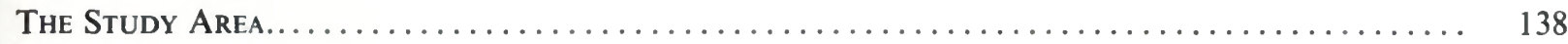

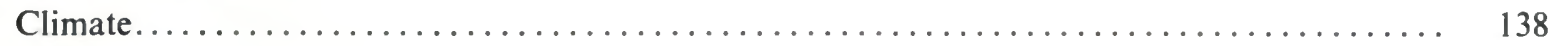

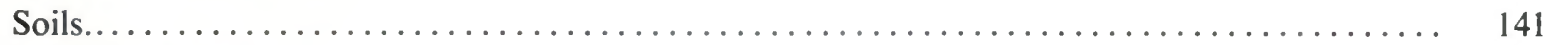

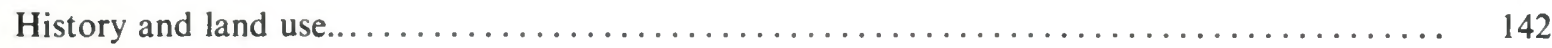

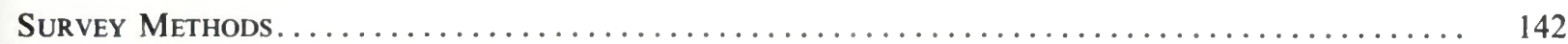

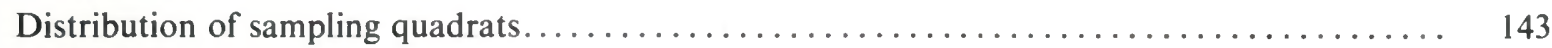

Quadrat size, shape and analysis................................... 143

Synthesis and results............................................ 143

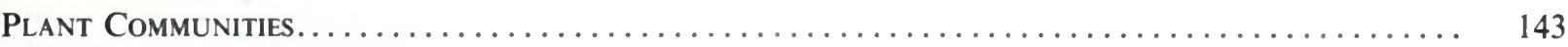

1. Communities of the elevated sandstone and felsite regions (Rhynchelytrum villosum-Schizachyrium jeffreysii Tree Savannas and Grasslands).............................

1.1 Eragrostis pallens-Burkea Tree Savanna............................. 146

1.1.1 Eragrostis pallens-Dombeya rotundifolia Variation...................... 146

A Eragrostis pallens-Pollichia campestris Sub-variation................ 146

B Transitional sub-variation............................... 148

C Transitional sub-variation............................... 148

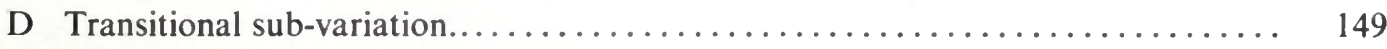

* Botanical Research Institute, Department of Agricultural Technical Services, Private Bag X101, Pretoria. 


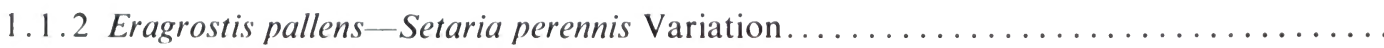

1.1.3 Eragrostis pallens - Trachypogon spicatus Variation.....

1.2 Barleria bremekampii-Diplorhynchus Savanna.

1.2.1 Pseudolachnostylis-Diplorhynchus Variation.

1.2.2 Enneapogon scoparius-Diplorhynchus Variation.

1.2.3 Burkea africana-Diplorhynchus Variation.

1.3 Eragrostis racemosa-Schizachyrium jeffreysii Tree Savanna and Grassland...........

1.3.1 Eragrostis racemosa-Combretum apiculatum Tree Savanna............... 151

1.3.1.1 Rhus leptodictya-Combretum apiculatum Variation................... 151

1.3.1.2 Cymbopogon plurinodis_Combretum apiculatum Variation............... 151

1.3.2 Eragrostis racemosa-Digitaria monodactyla Grassland.................. 152

1.3.2.1 Eragrostis nindensis - Digitaria monodactyla Variation................. 152

1.3.2.2 Tristachya rehmannii-Digitaria monodactyla Variation................. 153

2. Communities of flatbottomlands, excluding the self-mulching, vertic soils, and of termitaria (Panicum maximum - Acacia tortilis Tree Savannas and Termitaria Thickets)..............

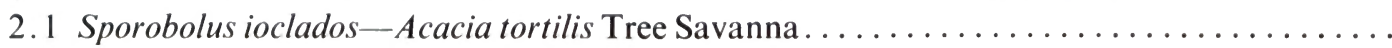

2.2 Euclea undulata-Acacia tortilis Tree Savanna and Termitaria Thickets.............

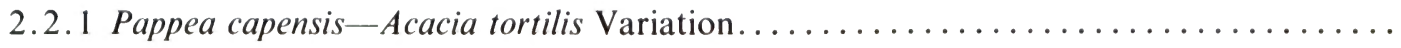

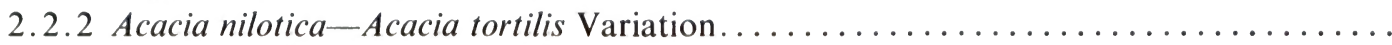

3. Communities of self-mulching vertic soils (Aristida bipartita-Setaria woodii Tree Savanna and Grassland).

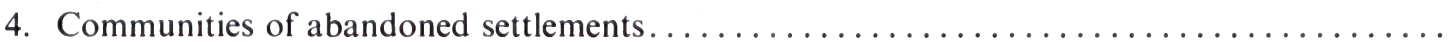

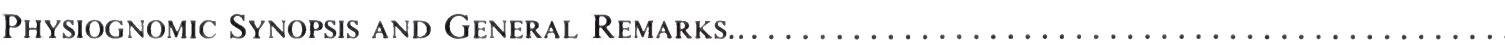

ACKNOWLEDGEMENTS

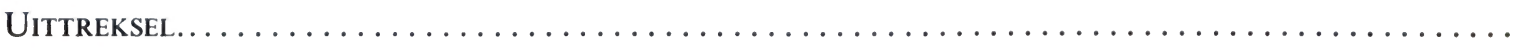

REFERENCES.

\section{INTRODUCTION}

The Nylsvley Nature Reserve covers 3120 ha in Acocks's (1953) Mixed Bushveld Veld Type. The Reserve comprises the farm Nylsvley 560 KR, situated between $24^{\circ} 36^{\prime}$ and $24^{\circ} 42^{\prime} \mathrm{S}$ latitude and $28^{\circ} 40^{\prime}$ and $28^{\circ} 44^{\prime}$ E longitude, on the Springbok Flats, $10 \mathrm{~km}$ south of Naboomspruit (Fig. 1). A savanna ecosystem project has been initiated on part of the Reserve by the Terrestrial Biology Section of the South African National Programme for Environmental Sciences. The purpose of this primary survey was to characterize the ecosystem study area floristically, to show its relationships to the vegetation in the rest of the Reserve and to supply basic information for range utilization by larger ungulates. The survey also formed part of the Terrestrial Biology Section's programme for inventorizing plant communities in permanently conserved areas at a semi-detailed level (Edwards, 1974). The Braun-Blanquet method (Westhoff \& Van der Maarel, 1973; Werger, 1974a), adopted by the Botanical Research Institute for primary semi-detailed surveys, was used. The survey was carried out at two levels of detail. The more detailed survey covers the areas chosen for intensive ecosystem studies and the more general survey covers the rest of the Reserve.

\section{THE STUDY AREA}

The Nylsvley Nature Reserve is situated in an extensive undulating to flat terrain between $1080 \mathrm{~m}$ and $1140 \mathrm{~m}$ altitude (Fig. 1).

Prominent hills are Maroelakop $(1140 \mathrm{~m})$ in the south and Stemmerskop $(1090 \mathrm{~m})$ further north. The small and shallow Nyl River runs across the
Reserve from south-west to north-east in a strip of flat bottomland that divides the study area into a number of gently sloping elevations. The southeastern elevations are underlain by sandstone, grits and conglomerate bands of the Waterberg System and the north-eastern elevations by felsite of the epicrustal phase of the Bushveld Igneous Complex. The area has a moderately low summer rainfall with a dry mildly frosty, winter period. Several soil series occur, associated with differences in geology and topography. The uplands have non-calcareous, relatively sandy soils with broad-leaved deciduous savannas and seasonal grasslands. The bottomlands have calcareous clay soils with microphyllous deciduous thorn savannas and seasonal grasslands. Termitaria with thickets are found throughout the felsite elevations and parts of the bottomlands (Fig. 2).

The Reserve was formerly used mainly for cattle grazing, but the natural state of the vegetation has been generally well conserved. Small parts of the bottomlands were ploughed and disturbed patches around abandoned settlements are still present on the sandstone elevations.

\section{Climate}

The climate, according to Köppen's System, is a hot, dry steppe with a dry winter period, designated BShw (Schulze, 1947).

Large diurnal variation in temperature during the cold winter months was regarded by Galpin (1926) as among the main limiting ecological factors of the Springbok Flats. As shown in Fig. 3, the cool period of water deficit stretches from April to September. 


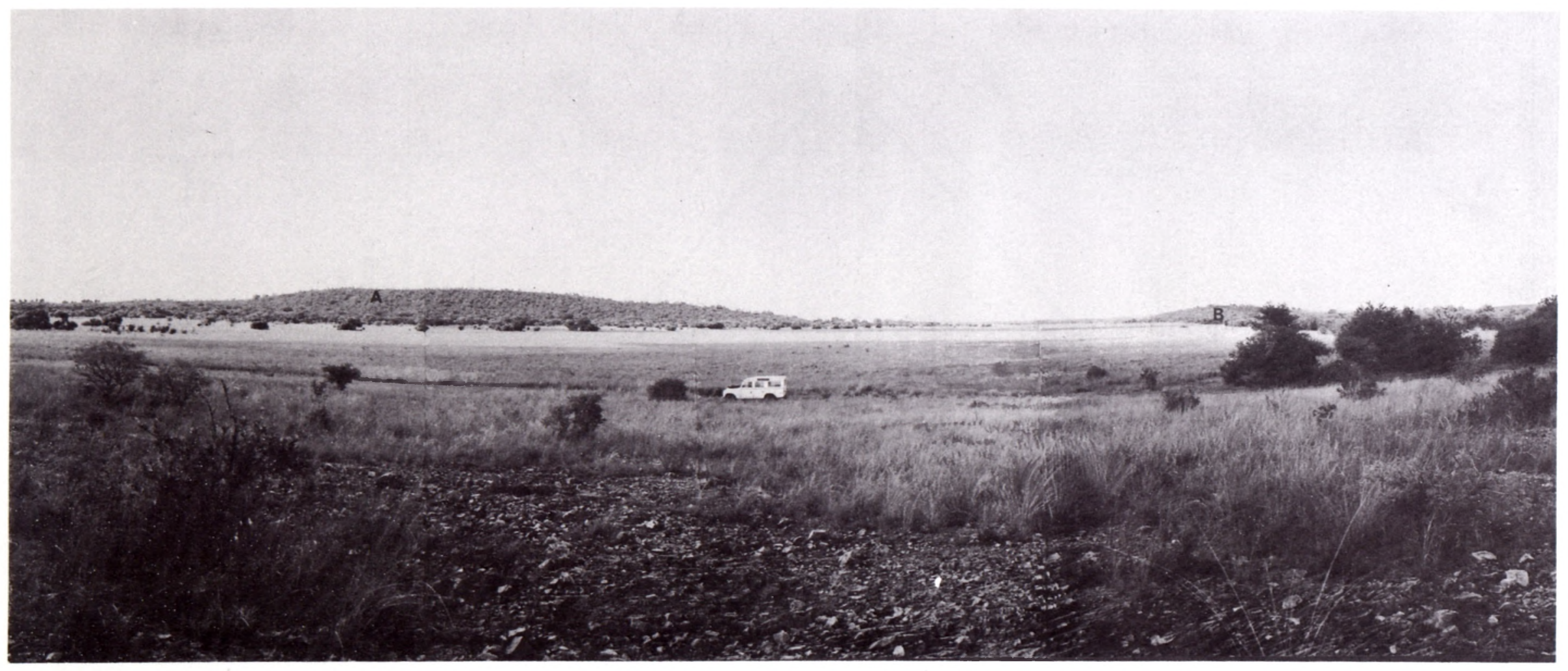

Fig. 2.-Part of the gently undulating to flat landscape of the Nylsvley Nature Reserve, with felsite elevation in foreground and two prominent sandstone hills, Maroelakop (A) and Stemmerskop (B). 


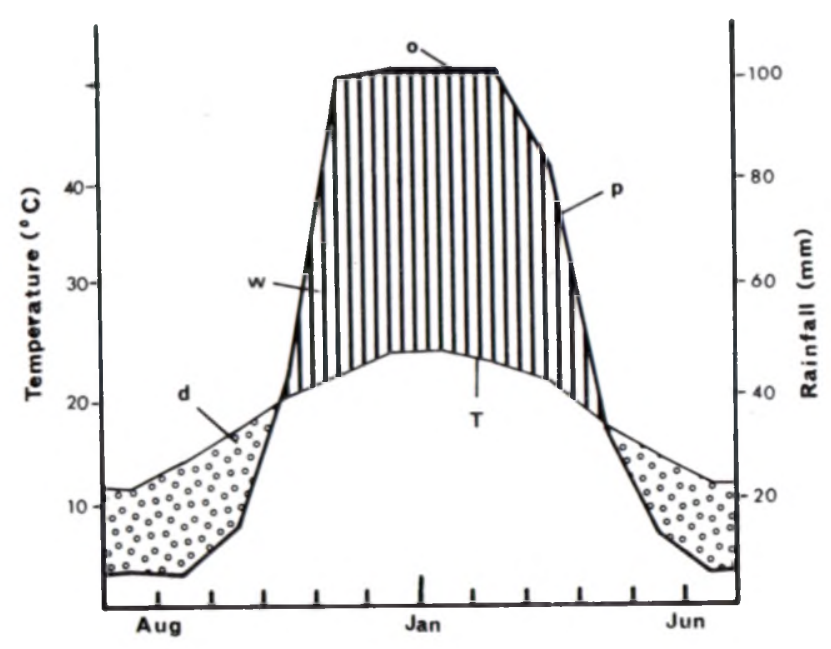

Fig. 3.-Climate diagram based on data from Mosdene $590 / 486$ and Nylsvley 590/307 Weather Stations (Weather Bureau, 1954 \& 1965), drawn after Walter \& Lieth (1960). $\mathrm{p}=$ mean monthly rainfall in $\mathrm{mm}$

$\mathrm{T}=$ mean monthly temperature in ${ }^{\circ} \mathrm{C}$

$\mathrm{d}=$ dry season

$w=$ wet season

$\mathrm{o}=$ mean monthly rainfall over $100 \mathrm{~mm}$ (scale reduced to $1 / 10)$.

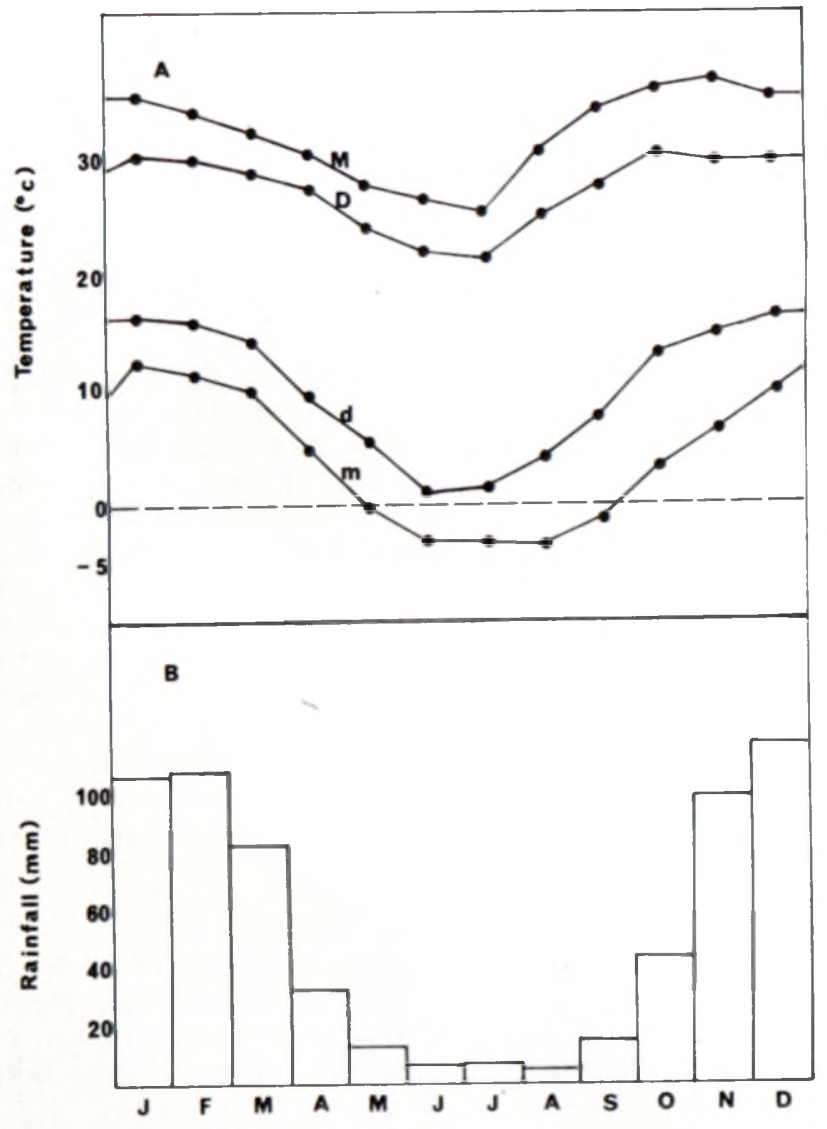

Fig. 4.-A. Mean maximum and minimum temperatures at Mosdene (Weather Bureau, 1954).

$\mathbf{M}=$ mean monthly maximum

$\mathrm{D}=$ mean daily maximum

$\mathrm{d}=$ mean daily minimum.

$\mathrm{m}=$ mean monthly minimum

B. Mean monthly rainfall at Nylsvley (Weather Bureau, 1965.)

\section{Temperature}

Temperatures recorded over the 10 year period 1920-1929 at the Mosdene 590/486 weather station, $10 \mathrm{~km}$ north-east of Nylsvley, give an indication of temperatures that may be expected on the Reserve (Weather Bureau, 1954; Fig. 4).

The station is situated at $1097 \mathrm{~m}$ altitude in a slightly elevated part of similar terrain. Ground frost may be expected daily in June and July, when mean daily minimum Stevenson Screen temperatures, which are considered as being generally $3{ }^{\circ} \mathrm{C}$ higher than ground minimum temperatures (Schulze, 1965), are $1,3{ }^{\circ} \mathrm{C}$ and $1,0{ }^{\circ} \mathrm{C}$ respectively. Occasional ground frost occurs from May until September, during which period mean monthly minimum temperatures range from $-0,2$ to $3,5^{\circ} \mathrm{C}$. These marginal freezing temperatures suggest differences in frequency and severity of frost with slight differences in topography as a result of cold air drainage. This suggestion is confirmed by $\mathrm{Mr}$ E. A. Galpin's observations on Mosdene (pers. comm.).

At Nylsvley cold air would accumulate in the northern felsite area, which is at the lower end of a broad, shallow valley originating at the Waterberg Mountains $7 \mathrm{~km}$ to the west; in a moderately sloping valley of the sandstone area and on the bottomlands.

\section{Wind}

Prevailing winds are east in summer and west in winter (Weather Bureau, 1960). Mr E. A. Galpin (pers. comm.) has observed that trees rapidly shed their leaves after a drying westerly wind followed by cold winds from the south. This effect is modified by prevailing soil moisture conditions.

\section{Rainfall}

Rainfall data are based on 40 years' records from the Nylsvley 590/307 weather station, situated on the Reserve at $1097 \mathrm{~m}$ altitude (Weather Bureau, 1965). The average annual rainfall is $630 \mathrm{~mm}$. In about three quarters of recorded years the rainfall exceeded $85 \%$ of the normal (i.e. of the average for 30 years). An average number of 62 days per year are rainy and $85-90 \%$ of the normal annual rainfall falls from October to March (Weather Bureau, 1957).

\section{Soils*}

The soils on Nylsvley may be grouped into five broad categories:

\section{(a) Litholitic soils}

These soils, found on the felsite and sandstone elevations, consist of unconsolidated material or hard rock with a minimum of soil particles.

\section{(b) Non-calcareous, well drained sandy soils}

Soils of this category also occur on the elevated parts. The well drained soils on felsite are shallow with an orthic A-horizon on unconsolidated material or rock, and belong mainly to the Mispah Series.

Well drained sandstone soils may be shallow, belonging to the Mispah Series, or deep with orthic A-horizons underlain by apedal B-horizons. The Hutton Form is a medium to coarse sandy soil with a red B-horizon and occurs on the upper slopes. The Clovelly Form has a yellow B-horizon and is found on lower slopes. Several series are distinguished and together form a toposequence. The sequence from

* Information on soils was provided by Prof. H. J. von M. Harmse and Mr P. J. Botha of the University of Potchefstroom, who did a soil survey on Nylsvley. 


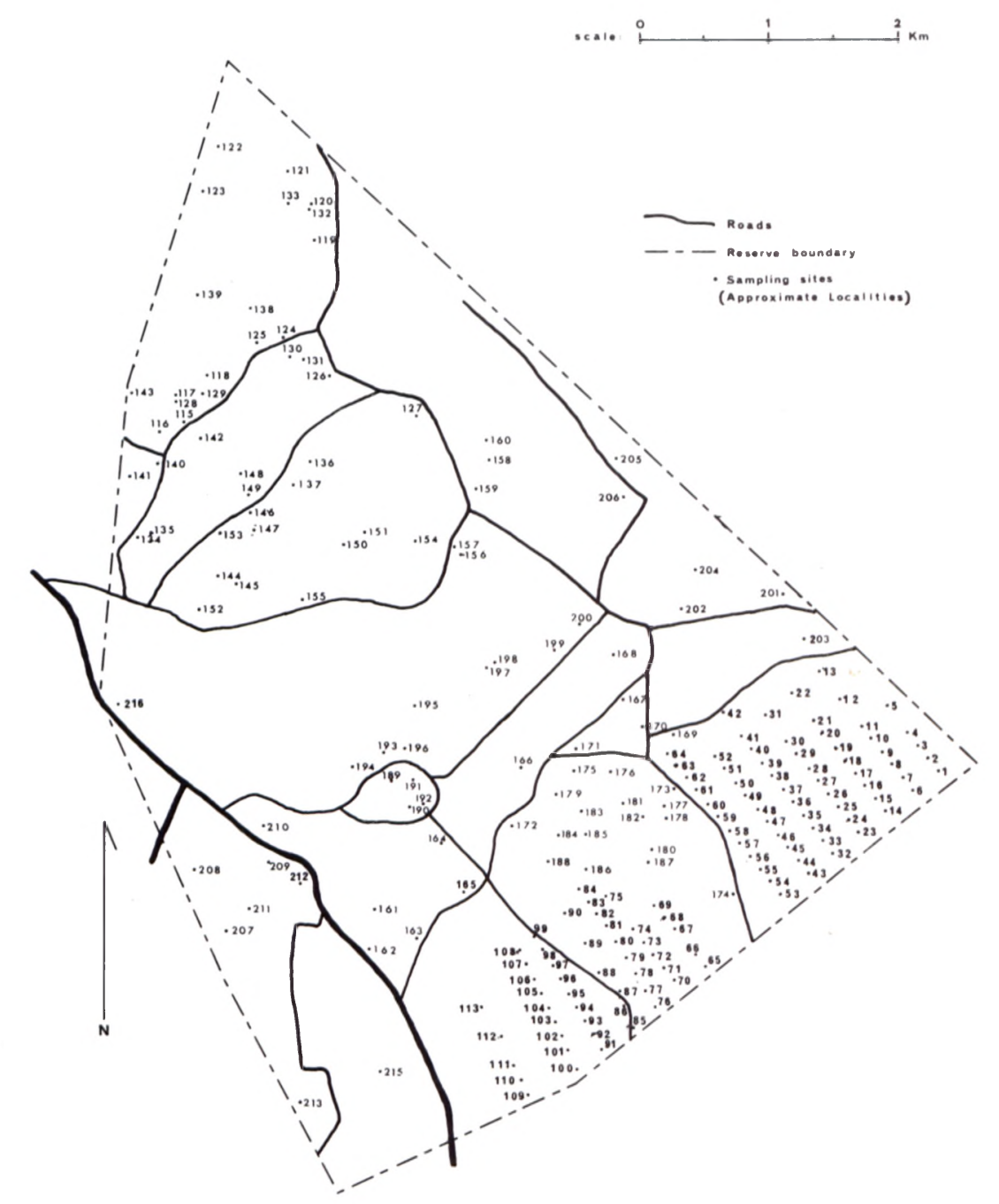

Fig. 5.-Distribution of quadrats in the Nylsvley Nature Reserve.

upper to lower slopes is: distrophic, mesotrophic and eutrophic Hutton soils, followed by distrophic and mesotrophic Clovelly soils.

\section{(c) Non-calcareous, poorly drained sandy soils}

Poorly drained sandy soils occur at the footslopes of the elevated areas and in elevated depressions. They are classified into the Wasbank, Longlands, Fernwood, Avalon and Mispah Forms. Wasbank and Longlands soils have perched gley horizons overlying mottled, plinthic B-horizons. Fernwood soils consist of a shallow orthic A-horizon on regic sand and Avalon soils have an orthic A-horizon, a yellow apedal Bhorizon and a soft plinthic B-horizon with mottling. Klipfontein soils (Mispah Form) are shallow and underlain by a hard flintite bank.

\section{(d) Calcareous alluvial soils}

The lowlands have a variety of alluvial soils. High clay content soils occur furthest from the Nyl River; lighter soils have been deposited closer to the river beds; and along the streams relatively sandy river banks have formed. The heavy soils, with more than $55 \%$ clay, belong to the Shephardvale Series and lighter soils, with $35-55 \%$ clay, are classified as Lindlay Series. Both series belong to the Valsrivier Form. The soils have orthic A-and strongly structured B-horizons. Soils of the Limpopo Series (Oakleaf Form), with a weak-structured B-horizon have developed on the river banks. (e) Calcareous, vertic black clay soils

These deep, black soils occur in the bottomland south of the alluvium. A vertic or melanic A-horizon is characteristic. Three soil series are recognized here. The Arcadia Series (Arcadia Form) is the most extensive, consisting of a thick, strongly vertic Ahorizon on unconsolidated material or rock. As a result of alternate wetting and drying the soil surface tends to form very fine blocky mulch or loose granular structures. This is a pure vertic soil with gilgai microrelief. The Gelykvlakte Series (Arcadia Form) differs in that the soil surface is not mulching but crusting, forming little cracks. Soils of the Bonheim Series (Bonheim Form) have a melanic A-horizon, with moderate to strong structure, overlying a dark-brown structured B-horizon.

\section{History and land use}

The following account of the history and land use of Nylsvley was extracted from an unpublished report by Grunow (1974). The information was supplied by Mr G. Whiteholise, previous owner of the farm Nylsvley.

\section{Cattle grazing system}

In 1945, when Mr Whitehouse started farming on Nylsvley, there were approximately 700 head of cattle. In recent years the number has been reduced to approximately 500 animals, representing a stocking rate of approximately 6 ha/head. The number of herds varied from three to four. 


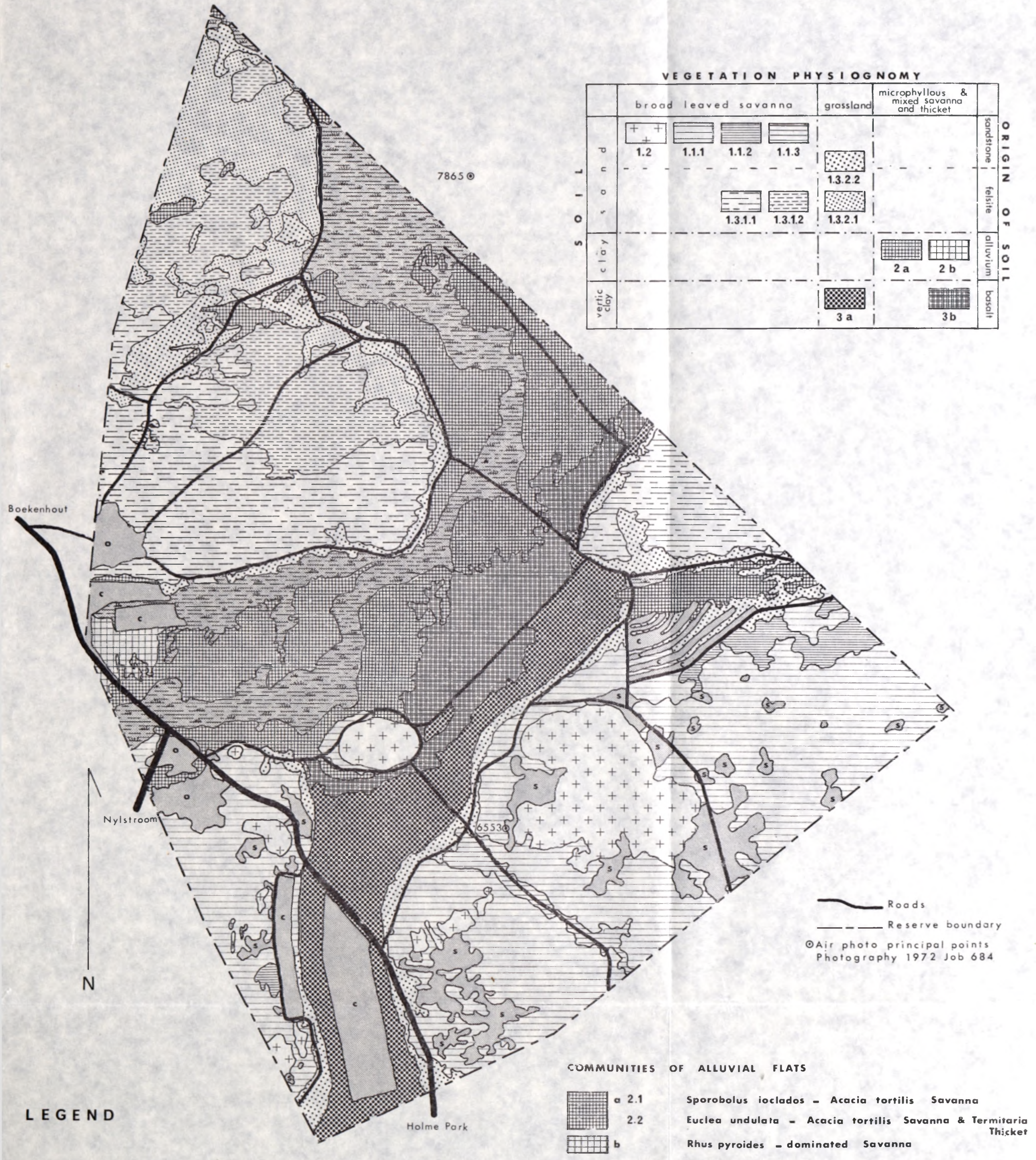

COMMUNITIES OF ELEVATED SANDSTONE AND FELSITE REgIONS

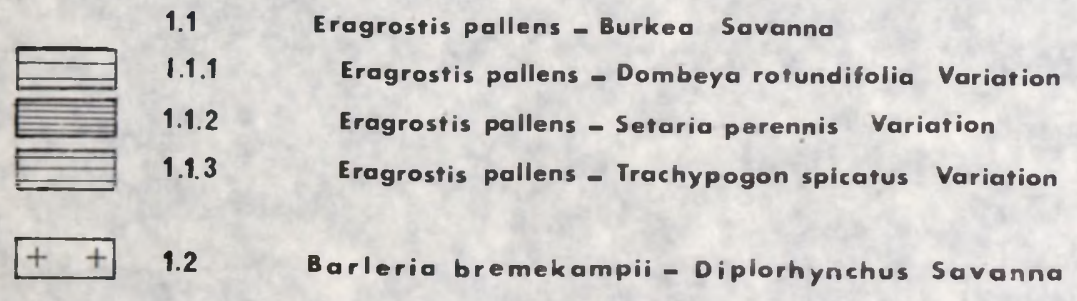

13 Eragrostis racemosa - Schizachyrium jeffreysii Savanna and Grassland

1.3.1 Eragrostis racemosa - Combretum apiculatum Savanna

1.3.1.1 Rhus leptadictya - Combretum apiculatum Variation

1.3.1.2 Cymbopogon plurinodis - Combretum apiculatum Variation

1.3.2 Eragrostis racemosa - Digitaria monodactyla Grassiand

1.3.2.1 Eragrostis nindensis - Digitaria monodactyla Variation

1.3.2.2 Tristachya rehmannii - Digitaria monodactyla Variation
COMMUNITIES OF SELF-MULCHING VERTIC SOILS Aristida bipartita - Setaria woodii Savanna and Grassland

Eanintitit Savanna Variation

而 $3 \mathrm{~b}$ Grassland Variation

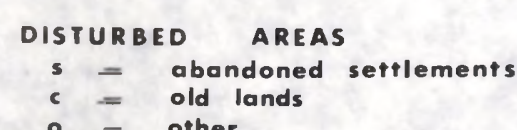



The number of grazing camps has been gradually increased to 25 , the main camps ranging in size from $200-250$ ha, except for one that is approximately 400 ha. Fifteen smaller paddocks serve, for example, for keeping bulls and as maternity camps. Water supply for the cattle comes from the Nyl River and from two boreholes, situated in the bottomland near the sandstone elevations.

The cattle were rotated, within limits set by water supplies and field conditions, as determined by rain, so that the whole farm was regularly grazed. The most palatable grass species were not overgrazed and rest periods for the vegetation were provided.

Three weeks after the first good rains, usually in October, the cattle were moved to the savannas and grasslands of the felsite area. From there they went to the savannas of the extensive sandstone area, where they stayed from mid-January until mid-May. The latter area was divided into four camps and was grazed by two herds of cattle of 150 animals each. Two of the four camps were used during January and February and the remaining two camps during March and April. Grazing commenced on different camps each year. Sometimes, when a dry period was followed by heavy rain and the poisonous plant Dichapetalum cymosum grew rapidly in the savannas of the sandstone areas, the cattle had to be temporarily removed from these areas.

During the dry period of May until October the cattle stayed in the bottomland. The vegetation of the vertisols was used for cattle grazing between December and June.

\section{Non-domestic animals}

The number of antelope and other game on the farm varies considerably due to seasonal migrations. Approximate numbers and fluctuations are: 150-500 impala; 40-100 kudu, which enter the Reserve in December and stay for the summer; 20 duiker; 20 steenbuck; 8 reedbuck; 50-100 warthogs; and 40-200 monkeys and baboons. With improved veld conditions as a result of camping and stock reduction, impala have become an increasing nuisance. The effective rest period for a camp was usually shortened by the impala, which grazed the camp before the cattle or, preferably, thereafter when the grass was short. From February to October the impala are found mainly in the two northern camps of the sandstone area. Thereafter they go north and enter the felsite area across the bottomlands. When the marshy parts of the bottomlands are too wet to cross they stay in the lowveld savannas.

The game are taken as the approximate equivalent of 80 head of cattle, which gives a combined total stocking rate of 5,4 ha/head for Nylsvley.

\section{Fire}

The previous owner never burned the pastures intentionally. Incidental fires occurred over the whole farm at irregular intervals and it is estimated that approximately half the sandstone area burned once in five years. Most fires occurred in the far northern camp.

\section{Agronomy}

Approximately 50 ha of the vertisol bottomlands were cultivated and used regularly for cutting hay from fodder crops. The area was banked off about 20 years ago to prevent it from being flooded.

\section{Native settlements}

The disturbance of native settlements, abandoned since 1925, is still clearly apparent in the elevated sandstone areas. Trees must have been cleared by the occupants to construct huts and kraals and to win areas for cultivation. The settlements were sited on upland areas, well away from the bottomlands, probably because the uplands are warmer and have fewer mosquitoes.

\section{SURVEY METHODS}

The Braun-Blanquet method of sampling and synthesis as described by Westhoff \& Van der Maarel (1973) and Werger (1974a) was followed, except that in some instances quadrats were sub-sampled.

\section{Distribution of sampling quadrats}

Quadrats were distributed to include as much of the variety in the study area as possible and to be representative of homogeneous stands of vegetation. The strategies used to achieve this in the intensive study area differed from those in the rest of the Reserve.

\section{Intensive survey}

The numbers of the 108 quadrats laid out in the intensive study area are shown in Tables 1 and 2 . The quadrats were placed on or near grid intersections and are permanently marked. A grid system was used to ensure an even distribution of quadrats because of the high sampling intensity. The flat topography and tall trees also render orientation difficult. Grid points were spaced $125 \mathrm{~m}$ apart on $345^{\circ}$ (magnetic) compass lines in the denser savanna and $250 \mathrm{~m}$ apart in the more open savanna. The lines were $250 \mathrm{~m}$ apart and follow a gentle gradient from upper to lower slopes.

\section{Extensive survey}

To cover the variation and to obtain a reasonably even distribution of quadrats over the rest of the Reserve, sample points were chosen in the field as sampling proceeded. The number and approximate position of the 107 quadrats laid out are shown in Fig. 5.

\section{Quadrat size, shape and analysis}

It was estimated that quadrats of approximately $50 \mathrm{~m}$ radius are necessary to represent the structural composition of most stands adequately, particularly in the tree savanna of the intensive study area, where trees are widely spaced. However, such quadrats are unnecessarily large for the herb layer, which is adequately represented in $10 \times 20 \mathrm{~m}$ quadrats. Woody species were, therefore, recorded in larger quadrats where not adequately represented in $10 \times 20 \mathrm{~m}$ quadrats. Quadrat sizes are shown in Tables 1-6. In small stands of vegetation with irregular boundaries, as on some termitaria, quadrats of varying sizes and shapes were used.

In the intensive study area a structural analysis was made in addition to the standard analysis. The height ranges of different layers of individuals were recorded separately for every woody species. Cover-abundance was recorded for each layer.

The following scale, taken from Westhoff \& Van der Maarel (1973), was used to estimate cover-abundance:

$r$ : one or few individuals

+ : occasional and less than $1 \%$ of total plot area

1: abundant and with very low cover, or less abundant but with higher cover; in any case less than $5 \%$ of total plot area

2**: very abundant and less than $5 \%$ cover, or $5-25 \%$ cover of total plot area

* Given by Westhoff et al. (1973) as $5 \%$ but this seems to be a printing error (cf. Werger, 1974a).

* Subdivisions of this class are not shown in Tables 1-6. 
$2 \mathrm{~m}$ : very abundant

2a: $5-12,5 \%$ cover, irrespective of number of individuals

$2 \mathrm{~b}: 12,5-25 \%$ cover, irrespective of number of individuals

3: $25-50 \%$ cover of total plot area, irrespective of number of individuals

4: 50-75\% cover of total plot area, irrespective of number of individuals

$5: 75-100 \%$ cover of total plot area, irrespective of number of individuals.

The scale as given by Werger (1974a) defines more clearly what was understood as Class 1: "numerous but covering less than $1 \%$ of the quadrat area, or not so abundant but covering $1-5 \%$ of the quadrat area". The definition of class " $r$ " in Werger's (1974a) account suggests a stricter interpretation of this class than that held in this survey. The numerous " $r$ " in Tables 1-6 may therefore be taken as "+", which would correspond more with the normal practice for allocating "+".

\section{Synthesis and results}

The results of the synthesis are shown in Tables 1-6. Each column represents a quadrat and thus a stand of vegetation. The rows represent species occurring in these stands. Cover-abundance symbols for every species in each quadrat are entered in the matrix. Species with similar distribution patterns are grouped together and differentiate groups of stands, which differ in species composition. The relationships between the groups of stands are shown by the groups of differential species they have in common. On the basis of these relationships, closely related groups of stands are combined to form a hierarchy of larger groups of stands. Each stand group typifies a plant community at a particular level in the hierarchy of plant communities. Thus, the total species composition of any stand of vegetation, the characteristic species combination of any plant community and the various floristic relationships between individual stands and between communities are shown in the tables (Werger, 1974b).

Table 1 shows the community to which the intensive study area and some relevés from the rest of the Reserve belong. Other communities in the Reserve are shown in Tables 3-6.

Table 2 gives a structural analysis of the most important woody species in the intensive study area. The relevés are arranged in the same sequence as in Table 1 and lines between groups of relevés are in the same positions. Relevé Nos. 211, 210, 209, 207, 208, 171, 172, 169 and 170 are omitted because no detailed structural analysis was made.

Cover is presented in height classes. Several height classes may be combined to a height range on the bases of their similar distribution patterns. Table 2 shows how particular height ranges of some species can differentiate between communities. Two groups of species are shown:

(a) Species with height ranges that differentiate; and (b) species with height ranges that do not differentiate.

In many instances a single layer of individuals recorded in the field extends across more than one height class in Table 2 . The cover-abundance value in such a case is the total for the height classes concerned. This is indicated in the table by entering the coverabundance value in the lowest height class and an asterisk in the higher classes. For example, if a layer of individuals was recorded in the field as Burkea

africana, 4-6 $\mathrm{m}$, with cover-abundance of 1 , this value is entered as "l" in the row for B. africana, 4-5 $\mathrm{m}$, with an asterisk in the row for B. africana, $5-6 \mathrm{~m}$.

\section{PLANT COMMUNITIES}

The vegetation of the Nylsvley Nature Reserve is floristically divided into four major groups of communities:

(1) communities of the elevated sandstone and felsite areas;

(2) communities of termite mounds and of the flat bottomlands, excluding self-mulching, vertic soils;

(3) a bottomland community on self-mulching, vertic soils; and

(4) communities of abandoned settlements.

The plant communities are mapped in Figure 6.

1. Communities of the elevated sandstone and felsite areas (Tables 1-3) (Rhynchelytrum villosumSchizachyrium jeffreysii Tree Savannas and Grasslands)

The elevated sandstone and felsite regions have litholitic and shallow to deep, non-calcareous sandy soils. The vegetation comprises broad-leaved savannas and grassland. Savannas occur on the upper parts, where frost is relatively mild and soils are well drained. Grasslands occur on frostier lower slopes with impeded drainage. The differential species are given in Tables 1 and 3 . The most common ones are the grasses Rhynchelytrum villosum and Digitaria cf. eriantha.*

The group of species which differentiates this community is similar to the group that differentiates the Loudetia simplex-Aristida aequiglumis Woodlands, Shrublands and Grasslands on leached soils in the Rustenburg Nature Reserve (Coetzee, 1975), where the annual rainfall is approximately $100 \mathrm{~mm}$ higher than at Nylsvley. Related communities in similar rainfall areas were also described by Du Plessis (1972), Theron (1973) and Coetzee (1974). Marked differences with the Nylsvley community include, for example, the occurrence and high constancy of Loudetia simplex at Rustenburg and the high presence of Rhynchelytrum villosum and Schizachyrium jeffreysii at Nylsvley.

An example of closely related vegetation in an area where the rainfall is $100 \mathrm{~mm}$ lower than on Nylsvley is provided by Rutherford (1972) from the central portion of the Omuverume Plateau in South West Africa. Half the group of differential species of the Nylsvley Rhynchelytrum villosum-Schizachyrium

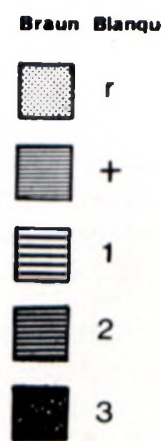

KeY TO FIG. 7.

* To be confirmed. 

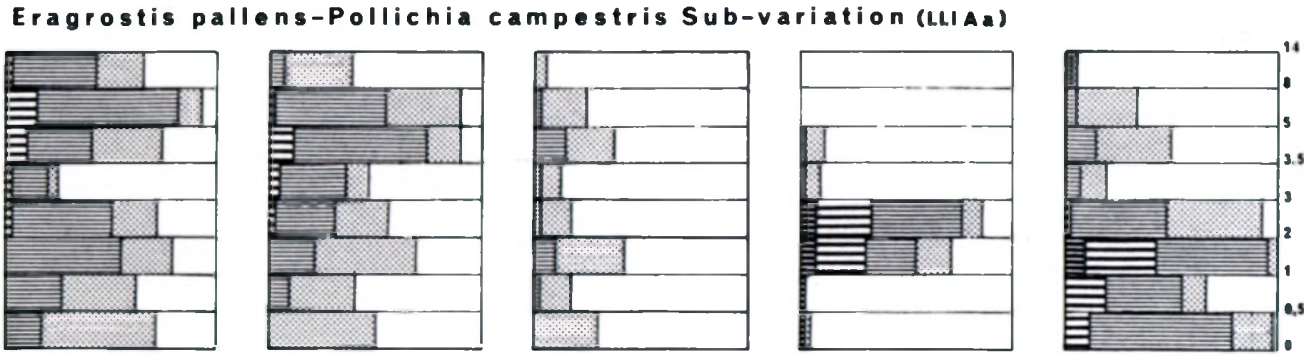

Eragrostis pallens-Pollichia campestris Sub-variation (LLA Ab)
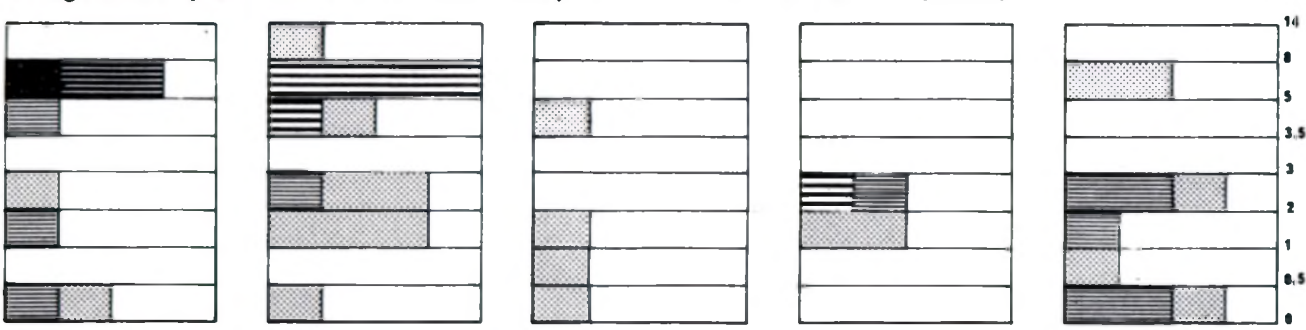

Transitional to Eragrostis pallens-Trachypogonspicatus Variation (LLIc)
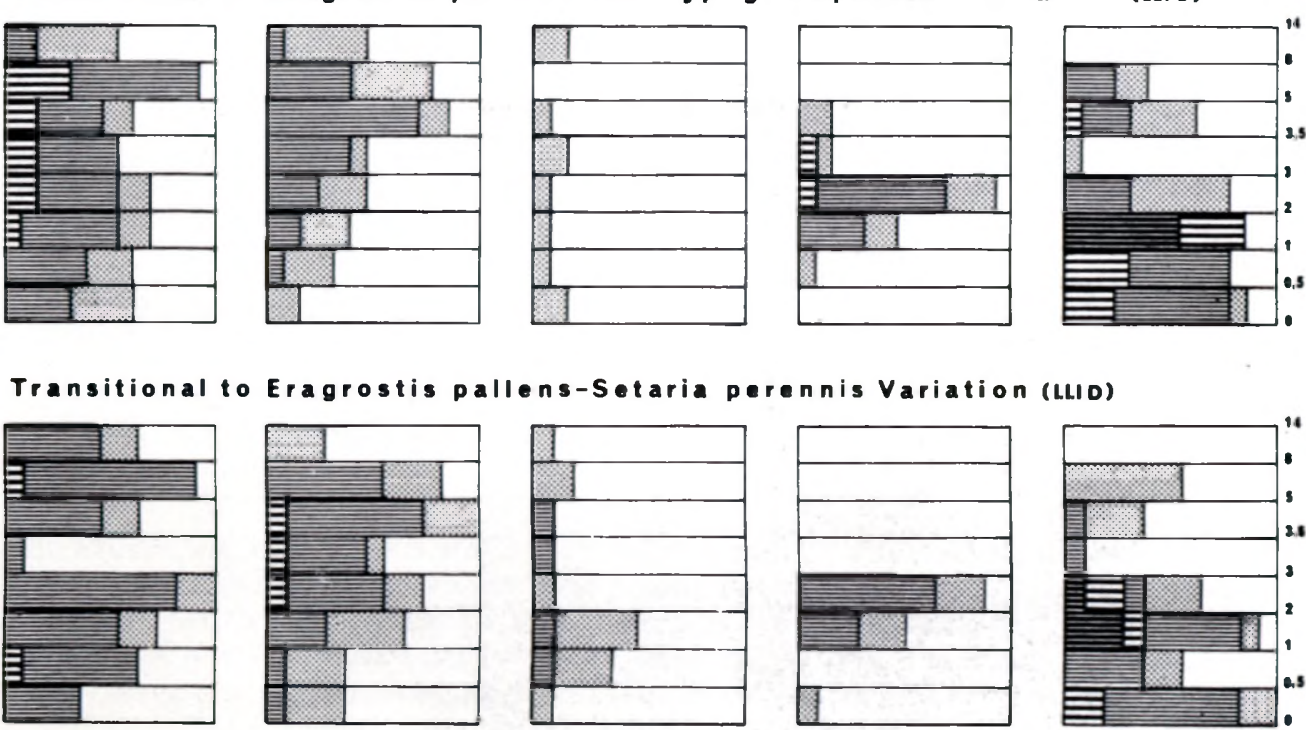

Eragrostis pallens-Setaria perennis Variation (LL2)
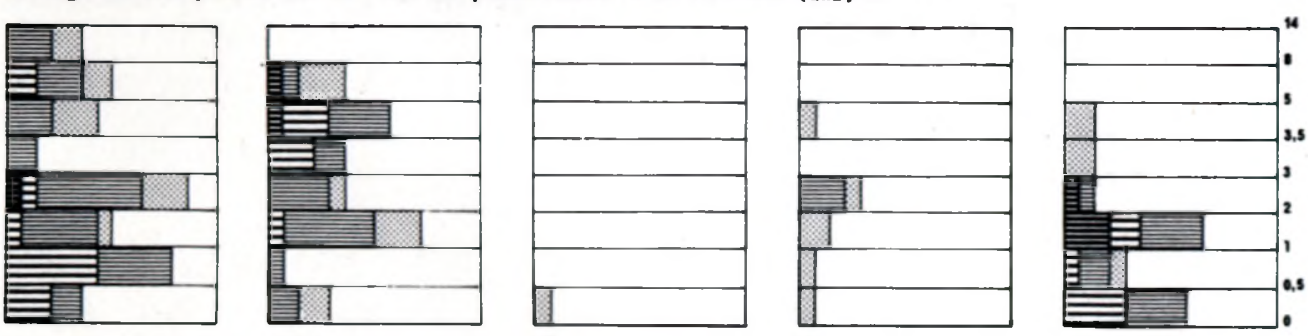

Eragrostis pallens-Trachypogon spicatus Variation (L..3)

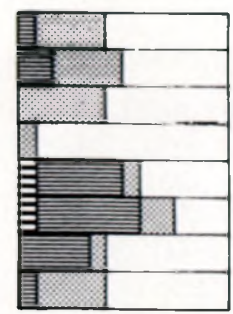

Burkea a frican a

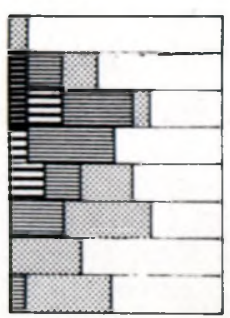

Terminalia sericea

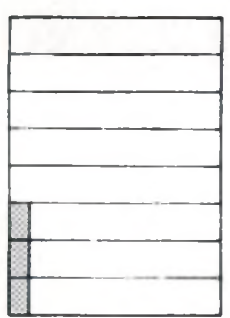

Combretum molle

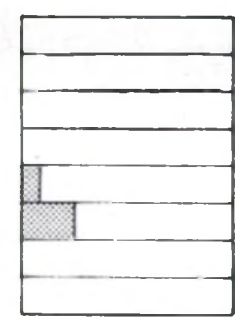

Grewia

flavescence

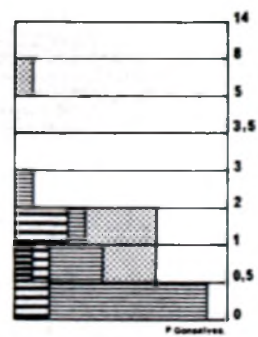

Ochna pulchra

FIG. 7.-Variations of Eragrostis pallens-Burkea Tree Savanna. Relative frequency of coverabundance classes in different height layers of dominant woody species. Full width of column represents $100 \%$ frequency (simplified after Table 2 ). See key on opposite page. 
jeffreysii community and several more species in the characteristic species combination of the Eragrostis pallens-Burkea Tree Savanna (see 1.1) are included in Rutherford's table of vascular plant species for his Burkea-Digitaria Woodland-savanna.

The Rhynchelytrum villosum-Schizachyrium jeffreysii community has three sub-divisions associated with clear topographic and soil differences. A group of species, which is restricted to this community but is seemingly sensitive to frost, and/or poor soil drainage, cuts across the three sub-divisions. This species group is absent from the lower slopes of the sandstone and felsite elevations and includes: Phyllanthus parvulus, Combretum molle, Euclea natalensis, Dombeya rotundifolia, Ozoroa paniculosa and Asparagus suaveolens. Other species indicate reticulate relationships between pairs of the three main groups.

\section{1 Eragrostis pallens-Burkea Tree Savanna (Tables 1 and 2)}

This community occurs on the non litholitic, sandy soils in the higher parts of the sandstone area. Soils are of the Mispah, Hutton and Clovelly Forms, which are moderately shallow to deep, well-drained and highly leached. The soils are mainly yellow-brown to red and have a low nutrient status. The topography is flat to very gently sloping, usually less than $2^{\circ}$. Occasional sandstone outcrops occur, but the degree of rockiness is always less than $1 \%$ of the plot size. Signs of shallow digging, small animal holes and antbear burrows are common. Usually there is a $5-10 \%$ cover of plant litter, consisting of leaves, mainly of Burkea africana and Ochna pulchra, grasses and twigs. Occasional dead trees lie on the ground.

The number of vegetation layers, their height and cover varies in the different community variations. A structural analysis is given in Table 2 and Fig. 7.

The community is differentiated by a large group of species as shown in Table 1. Constant differential species in the tree and shrub layer are Grewia flavescens, Strychnos pungens, S. cocculoides, Lannea discolor and Securidaca longipedunculata; and in the field layer, the grasses Eragrostis pallens, Aristida argentea and $A$. stipitata and the herbs Vernonia poskeana, Limeum viscosum, Cleome maculata, $C$. rubella and Dichapetalum cymosum.

Galpin (1926) described the Eragrostis pallensBurkea community as the Sandveld Association of the Springbok Flats. The woody component of the community corresponds very well, structurally and floristically, with Galpin's description. However, Galpin stated that "No specific grass can be said to dominate this Association".

The community consists of three variations, one of which has several sub-variations. The variations and sub-variations are correlated with a gradient from upper to lower slopes and with corresponding soil and climatic differences.

\subsubsection{Eragrostis pallens-Dombeya rotundifolia Variation}

This variation is the most extensive and occupies approximately 250 ha on the upper and middle slopes of the sandstone area, where the soils are well drained. The variation occurs on soils of the Hutton and Mispah Forms and on soils transitional to the Clovelly Form. Total tree cover varies from 20-60\%. Trees range in height from seedlings and low juveniles up to approximately $15 \mathrm{~m}$. The dominant trees are Burkea africana, Terminalia sericea and Combretum molle and the dominant shrubs are Ochna pulchra and Grewia flavescens. As shown in Table 2 and Fig. 9 the height ranges at which these species generally have their maximum cover vary considerably between species and between the different community subvariations. An average of 14 woody species was recorded per plot. Grass and forb cover varies from $15-65 \%$.

The community variation is differentiated from the two other variations on less well-drained soils and lower sites by Phyllanthus parvulus, Combretum molle, Euclea natalensis, Dombeya rotundifolia, Ozoroa paniculosa and Asparagus suaveolens. Elsewhere in the Reserve these species also differentiate between communities on well drained uplands and poorer drained bottomlands (Table 3). This variation is also structurally differentiated (Table 2) by some woody species, which are taller here than in the other two variations. These are: taller than $2 \mathrm{~m}$ Lannea discolor; taller than 2,5 m Ochna pulchra; and taller than $8 \mathrm{~m}$ Terminalia sericea. In the other two variations some of these species occur as coppicing shrubs with emergent dead twigs. As the twigs showed no sign of fire damage it seems likely that this is caused by accumulation of cold air and/or impeded soil drainage.

Three sub-variations, two of which are of limited extent, occur.

\subsubsection{A Eragrostis pallens-Pollichia campestris Sub- variation}

The largest and most typical part of the Eragrostis pallens-Dombeya rotundifolia Variation occurs on eu-, meso-, and distrophic Hutton soils of the middle and upper slopes.

This sub-variation includes a primary and secondary phase:

(a) The primary phase is characterized by the regular occurrence, and gradual change in cover values, of woody species over their entire height range (Table 2; Figs. 7 and 8).

There is a marked low occurrence of woody species in the 3-3,5 $\mathrm{m}$ height range where the tallest shrubs are mixed with low trees. Below this height range shrubs are dominant and above this height range trees are dominant, with a regular pattern of alternating dominant species:

Above $8 \mathrm{~m}$ : Burkea africana, followed by Terminalia sericea.

3,5-8 m: Burkea africana, followed by Terminalia sericea, Ochna pulchra and Combretum molle.

3-3,5 m: Low trees of Terminalia sericea, followed by Burkea africana and Ochna pulchra.

2-3 m: Grewia flavescens and Ochna pulchra (tall shrubs).

1-2 m: Ochna pulchra, followed by Grewia flavescens.

\section{Below $1 \mathrm{~m}$ : Ochna pulchra shrubs.}

Burkea africana is the most common young tree in the shrub layers below $3 \mathrm{~m}$, followed by Terminalia serice and Combretum molle, which are most abundant at $1-2 \mathrm{~m}$ and at $0-0,5 \mathrm{~m}$. The field layer, which has a total cover of $15-60 \%$, is dominated by Eragrostis pallens and Digitaria cf. eriantha.

The sub-variation is differentiated by a group of species with low cover. Constant differential species are, in the tree and shrub layer, Peltophorum africanum and Mundulea sericea and in the field layer, Panicum maximum, Pollichia campestris and Phyllanthus maderaspatensis. The grass Panicum maximum clusters under large trees and dense Grewia flavescens shrubs. 
TABLE 1. Eragrostis pallens-Burkea Tree Savanna.

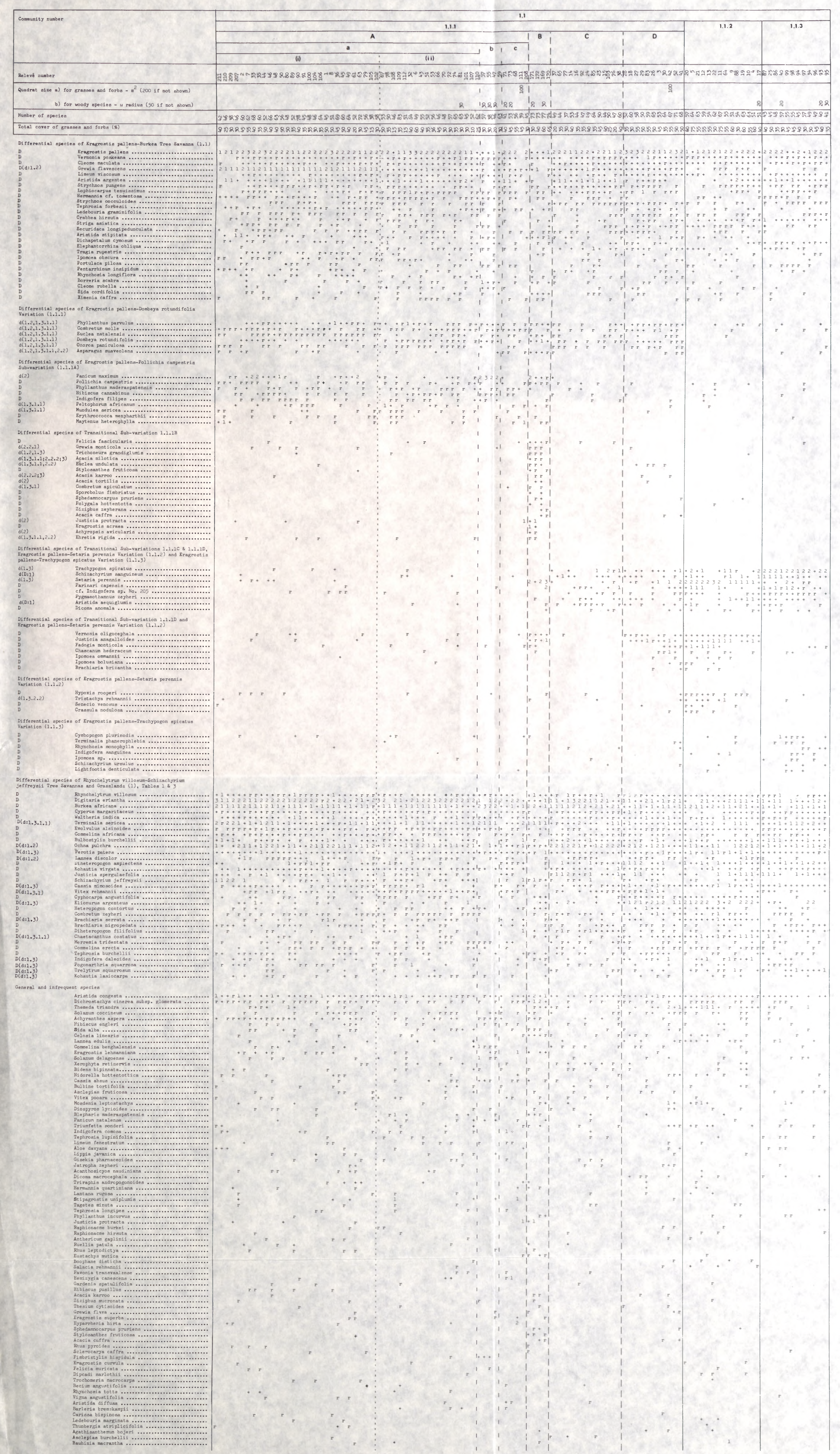

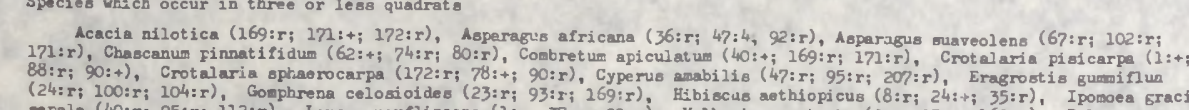

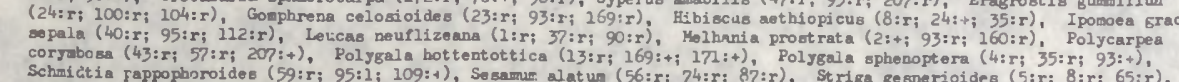

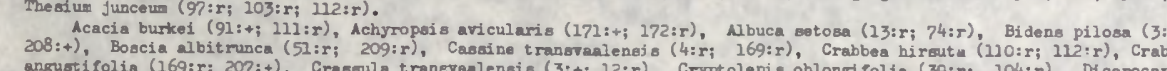

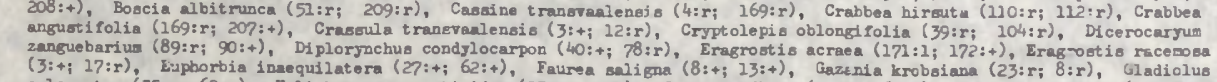

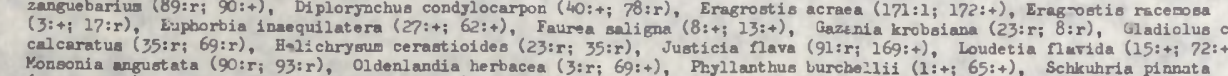

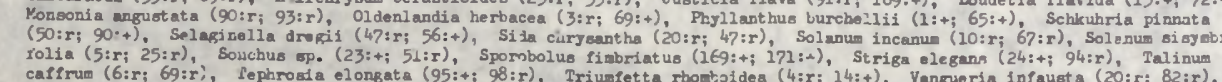

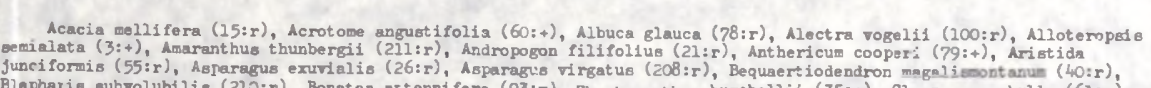

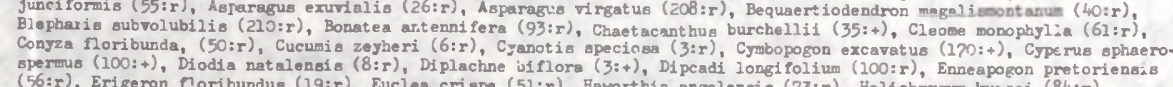

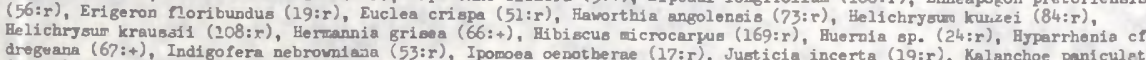

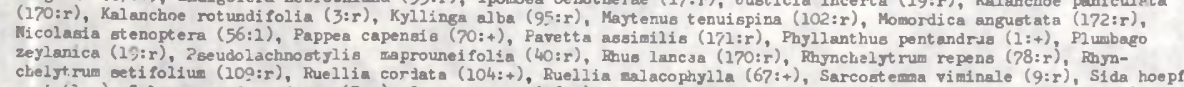

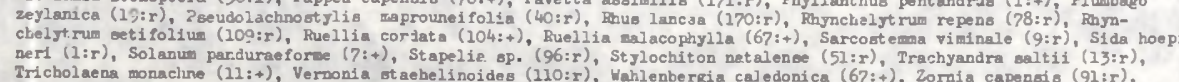



TABLE 2. Structural analysis of woody plants in Eragrosis pallens - Burkea Tree Savanna. Height classes in $\mathrm{m} ;{ }^{*}=$ same
cover abundance value as above.

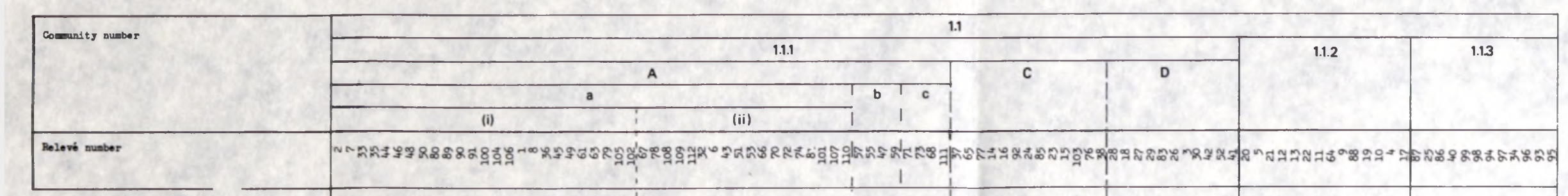

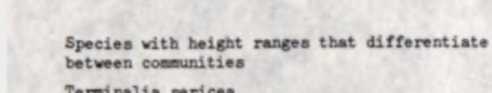

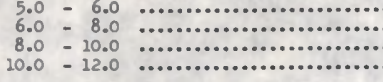

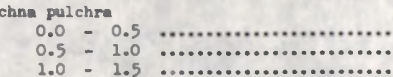

$5.0=$
6.0
8.0

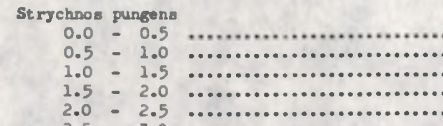

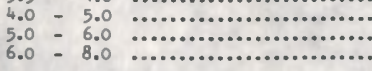

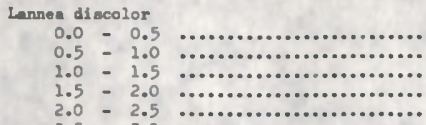

3.0
5.0
50.0
10.0
12.0

0.0

3.5
4.0
5.0
6.0
8.0

vit to. 0.0 .

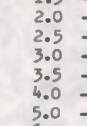

6.0
6.0
grovia

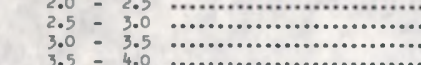

oworos pan

4.0
cosbretum
0.0
0.5

3.5
4.0
5.0
6.0
6.0

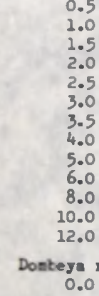

cind

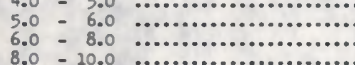

每.5

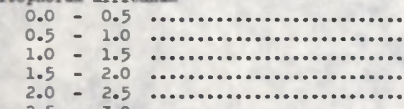

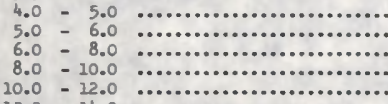

12.0
Mndoulea
0.0

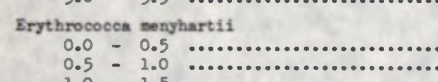

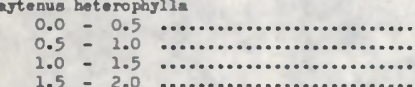

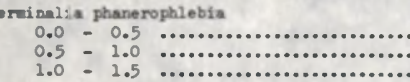

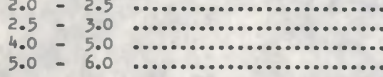

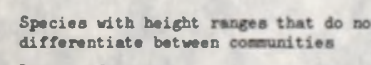

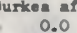

s.t.

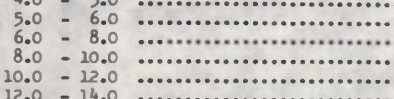

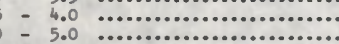

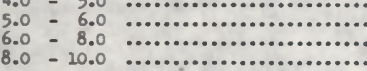

0.0
0.5
1.0
1.5
1.5
1.5
1.0
2.0

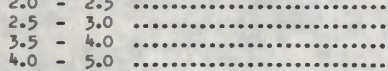

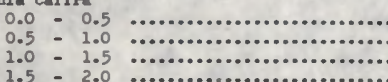

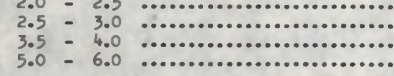

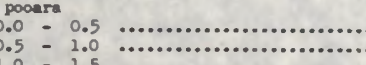

3.5
3.0
6.0
6.0
6.0 



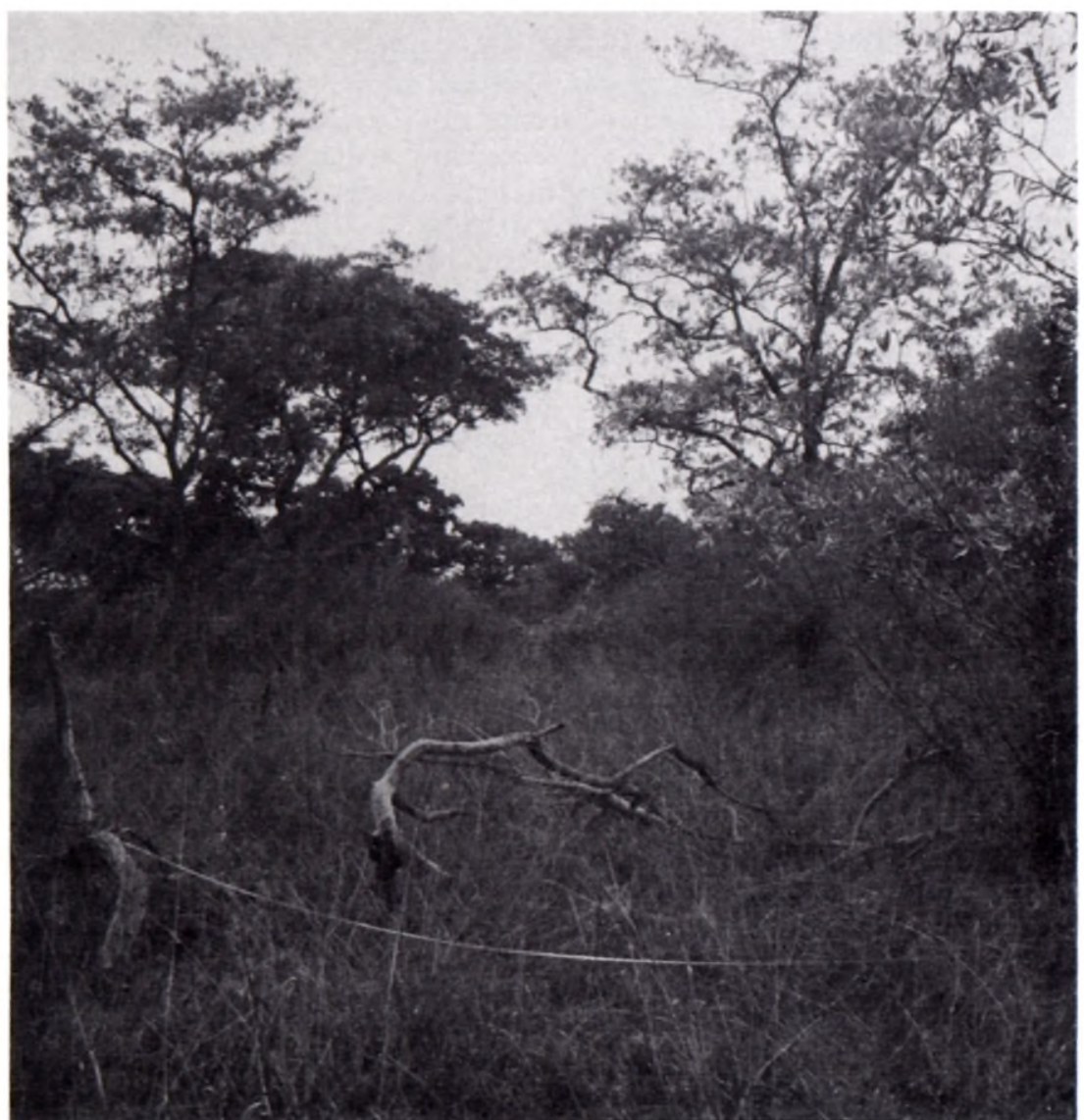

FIG. 8.-Vegetation structure in the primary phase of the Eragrostis pallens-Pollichia campestris Sub-variation.

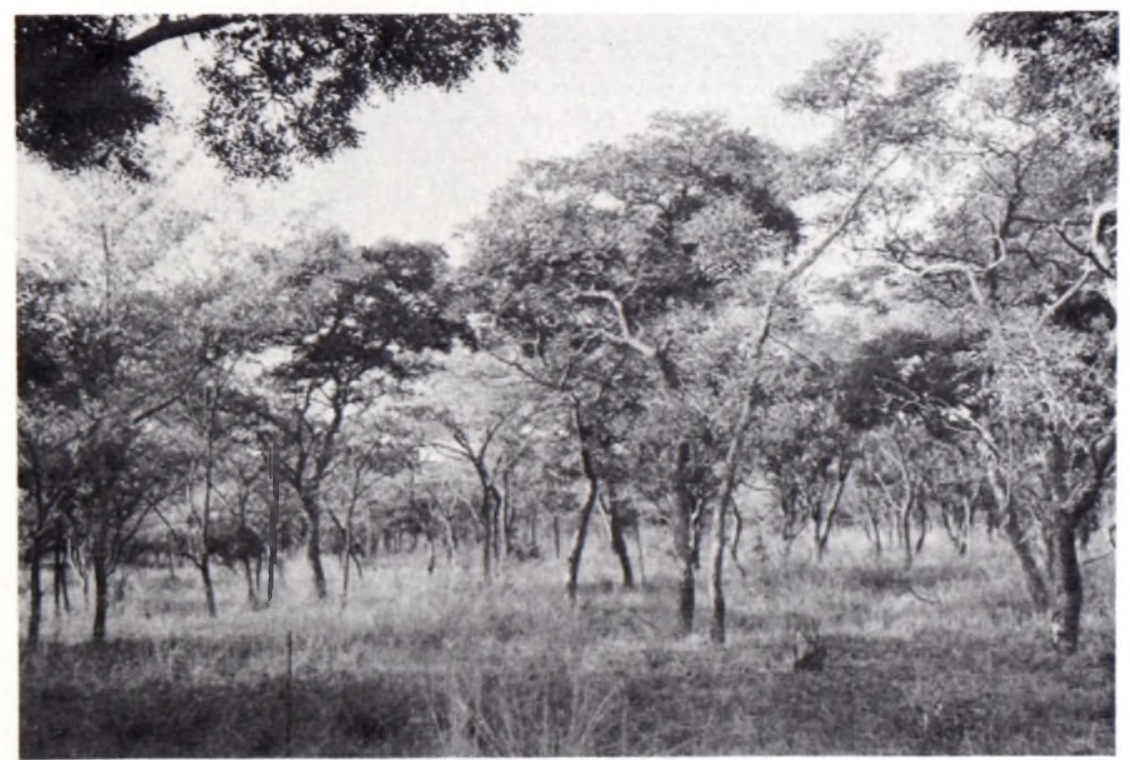

FIG. 9.-Vegetation structure in the secondary phase of the Eragrostis pallens-Pollichia campestris Sub-variation. 
In addition to the floristic similarities with the Burkea-Digitaria Woodland-savanna on the Omuverume Plateau already mentioned, there are similarities in structure and dominant woody species. The dominant woody species given by Rutherford (1972) are: Burkea africana; Terminalia sericea; Combretum psidioides subsp. dinteri; and Ochna pulchra, which is mentioned as very common and usually less than $3 \mathrm{~m}$ tall. In the Eragrostis pallens-Pollichia campestris Sub-variation at Nylsvley Combretum molle replaces $C$. psidioides and Grewia flavescens is also a very common woody species less than $3 \mathrm{~m}$ high. The low mounds occupied by Grewia flavescens at Nylsvley occur also at Omuverume where they are occupied by Combretum collinum. Both species generally form thickets on low mounds.

The dominant grasses in the Nylsvley community are Eragrostis pallens and Digitaria cf. eriantha. On the Omuverume Plateau, the Burkea-Digitaria community is considered to be in a near climax stage, probably because of protection from large grazing mammals by an encircling barrier of cliffs. The dominant grasses there are Digitaria polevansii, Brachiaria nigropedata, Andropogon gyanus and $A$. schirensis. On an adjoining plateau with seemingly identical abiotic conditions, but with cattle grazing, Rutherford (pers. comm.) noted that Eragrostis pallens was the dominant grass, as on Nylsvley. The other dominant grass on the grazed plateau was Arstida stipitata, which at Nylsvley has a high presence, occasionally with high cover. The high cover of Eragrostis pallens at Nylsvley seems, therefore, to be a result of grazing.

Minor structural units within the primary phase are (Table 2):

(i) Areas where 1,5-3 m Grewia flavescens shrubs cover $1-10 \%$ and where Euclea natalense and Cassia mimosoides have high presences.

(ii) Areas where 1,5-3 m Grewia flavescens shrubs cover less than $1 \%$ and where Vitex rehmannii has a high presence.

(b) The secondary phase occurs in small zones around old settlements (Fig. 9).

This secondary vegetation is typified in Relevé Nos. 47, 55, 57 and 59. Soils here are eutrophic, of the Hutton Form, and relatively rich in phosphate content. Plant litter of Burkea africana leaves, twigs and grasses covers up to $35 \%$ of the soil surface.

The vegetation structure differs from the primary phase in that trees are less regularly distributed over their entire height ranges; high cover values occur in discrete layers; and Burkea africana and Terminalia sericea both have their maximum cover values at $5-10 \mathrm{~m}$. Total cover in the dense layer is between 20 and $55 \%$. Dominant woody species at various heights are as follows (see Fig. 7 and Table 2):

Above $5 \mathrm{~m}$ : Burkea africana, followed by Terminalia sericea.

3,5-5 m: Terminalia sericea, followed by Burkea africana.

3-3,5 m: Terminalia sericea (tall shrubs), followed by Combretum molle (low trees).

2-3 m: Grewia flavescens, followed by Terminalia sericea and Ochna pulchra.

Below $2 \mathrm{~m}$ : Ochna pulchra.

Young trees of Burkea africana, Terminalia sericea and Combretum molle occur in the shrub layers. Cover in the field layer is between 5 and $50 \%$ and Panicum maximum is the dominant grass, followed by Digitaria cf. eriantha, Eragrostis pallens has less than $1 \%$ cover.

Peltophorum africanum, Mundulea sericea and Maytenus heterophylla, which are among the differential species for the sub-variation, are absent here, as well as Vitex rehmannii, which is common elsewhere. Several grasses which differentiate the Rhynchelytrum villosum-Schizachyrium jeffreysii community are absent. They are: Diheteropogon amplectens, $D$. filfolius, Schizachyrium jeffreysii, Elionurus argenteus, Brachiaria serrata, B. nigropedata, Pogonarthria squarrosa and Urelytrum squarrosum. Within the community Fimbristylis hispidula only occurs in three of the four relevés that typify the vegetation zones around old settlements.

(c) Relevé Nos 71, 73, 60,111 and 208, representing heterogeneous and disturbed quadrats, are grouped together in Table 1.

\subsubsection{B Transitional sub-variation}

One of the three sub-variations transitional to the variations on lower slopes fringes the northern footslopes of Maroelakop, occuring on very slightly sloping sites with eutrophic Hutton soils. The densely wooded vegetation is typified by four relevés, Nos. $171,172,169$ and 170, of which no detailed structural analysis was made.

An average of 74 species, including 19 woodies, was found per plot. This is the highest average on the Reserve.

The vegetation cover is usually between 1 and $5 \%$ at each of the following height levels: $10-14 \mathrm{~m}$; 8-10 $\mathrm{m} ; 3-5 \mathrm{~m}$; and a $0,5-3 \mathrm{~m}$ shrub layer. The field layer is up to $1,75 \mathrm{~m}$ high with $30-65 \%$ cover. Burkea africana, Terminalia sericea and Dichrostachys cinerea subsp. glomerata, are the dominant woody plants. Setaria perennis dominates the field layer and generally has a high cover, indicating moist conditions as in the Eragrostis pallens-Setaria perennis Variation (1.1.2).

Common differential species in the field layer are Felicia fascicularis, Stylosanthes fruticosa, Sporobolus fimbriatus, Sphedamnocarpus pruriens, Ziziphus zeyherana, Acacia caffra and Eragrostis acraea. The last four species occur only in this sub-variation. Some of the differential species are typical also of communities on the heavy lowland soils. These species are Acacia nilotica, A. karroo, A. tortilis, Ehretia rigida, Justicia protracta and Achyropsis avicularis. Further relationship with these communities is shown by the presence of Dichrostachys cinerea subsp. glomerata, in the tree and shrub layers; and Hibiscus engleri, Achyranthes aspera, Celosia linearis, Blepharis maderaspatensis and Eragrostis lehmanniana in the field layer. Vernonia oligocephala, Justicea anagalloides and Fadogia monticola have relatively high presence as in the Eragrostis pallens-Setaria perennis Variation (1.1.2).

This sub-variation is transitional to the Panicum maximum-Acacia tortilis Communities of bottomland soils on the one hand, and the Eragrostis pallensSetaria perennis Variation of lower sandstone areas on the other hand.

\subsubsection{Transitional sub-variation}

Another transitional sub-variation occurs on the high sandstone areas where outcrops are common and the soils are less deep and classified into the Mispah Series. Apart from considerably more Ochna pulchra shrubs and less Grewia flavescens shrubs there is no marked difference in dominants, structure and height with the typical sub-variation (1.1.1A; Fig. 7). 
Several species indicate a relationship with the two remaining variations on moister, lower sandstone areas (1.1.2 and 1.1.3). Such species are Trachypogon spicatus, Schizachyrium sanguineum, Parinari capensis, Pygmaeothamnus zeyheri and Aristida aequiglumis.

The sub-variation is transitional particularly to the Eragrostis pallens-Trachypogon spicatus Variation (1.1.3) of the slightly sloping valley west of Maroelakop.

\subsubsection{Transitional sub-variation}

On the middle slopes of the sandstone area where soils gradually grade from the Hutton to the Clovelly Form, a third transitional sub-variation occurs.

In dominants and structure the vegetation does not differ clearly from the previous or from the typical sub-variation (Table 2; Fig. 7). The same species mentioned under the former sub-variation (1.1.1C) indicate relations with the remaining two variations on lower slopes (1.1.2 and 1.1.3). The sub-variation is particularly related to the Eragrostis pallensSetaria perennis Variation (1.1.2). Common features are the constant high cover of Elionurus argenteus; and the presence of Vernonia oligocephala and Justicia anagalloides, which occur also in sub-variation 1.1.1B fringing Maroelakop.

\subsubsection{Eragrostis pallens-Setaria perennis Variation}

This variation occurs in lower sandstone areas on distrophic Clovelly soils (Mosdale Series) with medium sand.

The vegetation differs from the Eragrostis pallensDombeya rotundifolia Variation (1.1.1) of upper slopes in the presence, height and cover of various woody species (Table 2; Figs. 7 and 10).

Scattered individuals of Faurea saligna, up to $10 \mathrm{~m}$ tall, occur. The dominants in the tree and shrub layers are Burkea africana, Terminalia sericea and Ochna pulchra. Eragrostis pallens and Setaria perennis are dominant in the field layer.

The general height distribution of dominant woody species is as follows:

Above $8 \mathrm{~m}$ : Burkea africana, followed by Terminalia sericea.

5-8 m: Burkea africana, followed by Terminalia sericea and Ochna pulchra.
3-3,5 m: Terminalia sericea, followed by Burkea africana.

2-3 m: Burkea africana, followed by Terminalia sericea, Grewia flavescens and Ochna pulchra.

1-2 m: Ochna pulchra, followed by Burkea africana and Terminalia sericea.

Below $1 \mathrm{~m}$ : Ochna pulchra, followed by Burkea africana.

The average number of tree species per plot is seven, which is low compared to the average of 14 in the variation on upper slopes (1.1.1).

Total tree cover is considerably lower than in the latter Eragrostis pallens-Dombeya rotundifolia Variation, usually less than $5 \%$. Shrub cover is less than $10 \%$ and a field layer of up to $1,8 \mathrm{~m}$ high covers $30-75 \%$.

Differential species are few and of low constancy. They include Hypoxis rooperi and Tristachia rehmannii. The high cover of Setaria perennis and Elionurus argenteus is characteristic. Brachiaria serrata, Themeda triandra and Chaetacanthus costatus have high constancy.

\subsubsection{Eragrostis pallens-Trachypogon spicatus Variation}

This variation occurs in the moderately sloping valley west of Maroelakop on coarse textured mesotrophic Clovelly soils (Sibakwe Series). The soils are better drained than those of the former variation because of their location at higher slope positions and their coarse texture.

The vegetation resembles the previous variation in presence, height and number of woody species. However, Terminalia sericea has generally a higher cover than Burkea africana at heights above $3,5 \mathrm{~m}$. Total tree cover is also greater in this variation and can be up to $20 \%$. Common woody species at different heights are (Fig. 7 and Table 2):

Above $3 \mathrm{~m}$ : Terminalia sericea, followed by Burkea africana.

2-3 m: Burkea africana, followed by Terminalia sericea.

1-2 m: Burkea áfricana and Ochna pulchra, followed by Terminalia sericea.

Below $1 \mathrm{~m}$ : Ochna pulchra, followed by Burkea africana and Terminalia sericea.

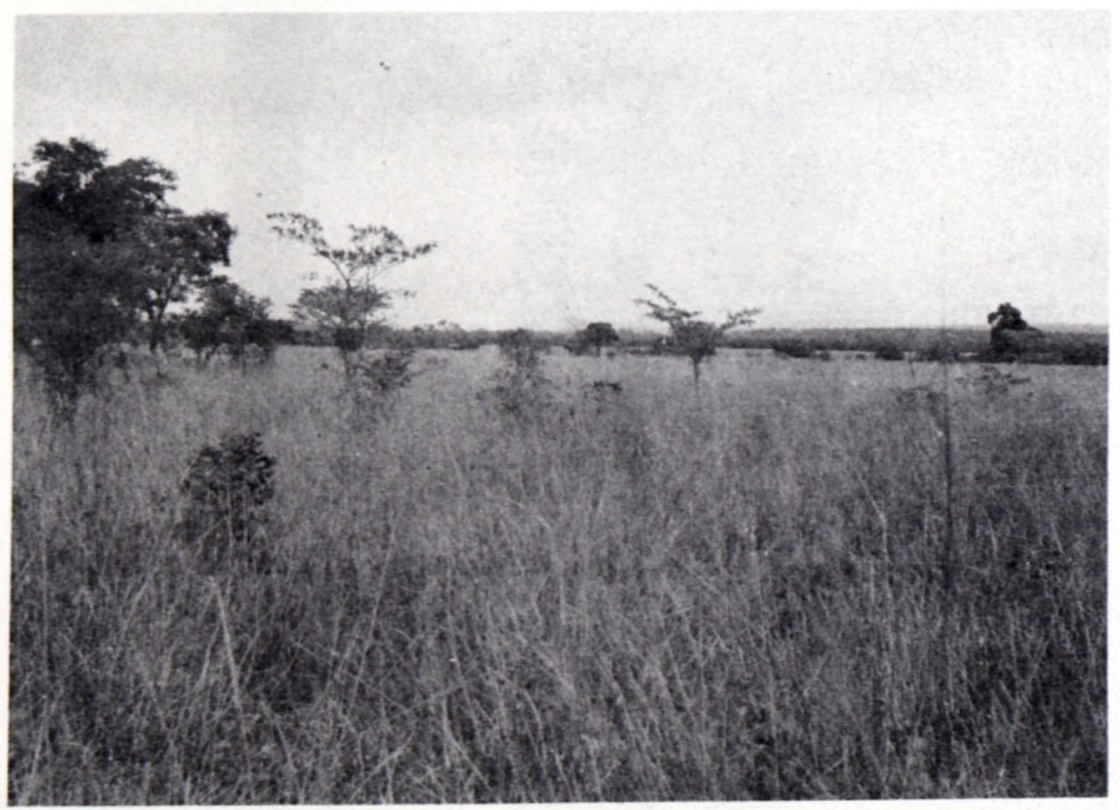

FIG. 10.-Physiognomy of the Eragrostis pallens-Setaria perennis Variation. 
A low average of seven woody species was recorded per plot. Trachypogon spicatus and Eragrostis pallens are dominant in a $1,75 \mathrm{~m}$ tall field layer with a total cover of $30-50 \%$.

A small group of species with low constancy differentiates the variation. Conspicuous ones include Terminalia phanerophlebia in the tree and shrub layer and Cymbopogon plurinodis in the field layer. The high cover of Trachypogon spicatus is also characteristic.

\subsection{Barleria bremekampii-Diplorhynchus Tree Savanna (Table 3).}

This community occurs on gentle to moderately steep slopes of rocky sandstone hills and ridges, where soils are litholitic and rocks cover 10-60\% (Fig. 11).

The vegetation is broad-leaved savanna. Uneven, broken areas carry a dense woody vegetation and on more even terrain trees are less dense. Trees and shrubs of varying age and height occur in all parts of the savanna.

Common differential species include the tree Diplorhynchus condylocarpon, the shrub Barleria bremekampii and the forbs Tephrosia longipes, Rhynchosin totta, Corchorus kirkii, Indigofera comosa, Asparagus saundersiae and Euphorbia neopolycnemoides. Another differential species, Xerophyta retinervis, which occurs typically on very shallow soils and amongst outcrops, is conspicuous because of its unusual growth form of a protective cylinder of moisture absorbing leaf sheaths round a thin woody stem with adventitious roots (cf. Ayensu, 1973).

Three community variations correspond closely with the main physiognomic differences and are related to rockiness. Differences in aspect and degree of slope are apparently of less importance.

\subsubsection{Pseudolachnostylis-Diplorhynchus Variation}

This savanna is typical of the Maroelakop area, where it occurs on various aspects and degrees of slope, with $30-60 \%$ rock cover.

The vegetation has a dense phase on uneven rocky sites where trees are between 4 and $8 \mathrm{~m}$ high with $30-60 \%$ cover, and a more open phase with 4-6 m tall trees covering 5-20\%. Diplorhynchus condylocarpon is the only dominant tree. A $0,5-2,5 \mathrm{~m}$ shrub layer covers up to $15 \%$ of quadrats with dense stands of Canthium gilfillanii; and a field layer of up to 1,50 $\mathrm{m}$ has $5-40 \%$ cover, depending on the amount of rock. Schizachyrium jeffreysii is usually the dominant grass and Setaria lindenbergiana is locally dominant.

Differential species include the tree Pseudolachnostylis maprouneifolia, the shrub Canthium gilfillanil and the forb Polygala rehmannii. The habitat of the relatively open phase of this community variation is very similar to that of the Enneapogon scoparius-. Diplorhynchus Variation (1.2.2) on other rocky sandstone areas.

\subsubsection{Enneapogon scoparius-Diplorhynchus Varia- tion}

The moderately open savanna which covers most of the relatively unbroken rocky slopes of Stemmerskop and the western sandstone ridges belongs to this variation, which occurs on northerly and southerly aspects with moderately steep slopes and 30-60\% rock cover.

The trees are mainly $4-6 \mathrm{~m}$ tall with $5-20 \%$ cover. Shrub cover varies from $1-15 \%$ and grass and forb cover is between 25 and $50 \%$. Combretum molle and Croton gratissimus are the dominant trees and Enneapogon scoparius is the dominant grass.

Common differential woody species include Croton gratissimus and the dwarf shrub Rhus magalismontanum. Differential species in the field layer are Enneapogon scoparius and the forbs Becium angustifolium and Vernonia sutherlandii.

The characteristic presence and dominance of Croton gratissimus and Enneapogon scoparius is indicative of hot and dry conditions (cf. Theron, 1973; Coetzee. 1974; and 1975).

\subsubsection{Burkea africana-Diplorhynchus Variation}

This variation occurs on gentle slopes with 10-20\% outcrop. Trees are between 4 and $6 \mathrm{~m}$ high and usually have up to $5 \%$ cover, which is much lower than in the previous variations on rockier sites. Shrubs cover up to $5 \%$ of quadrats, while grasses and

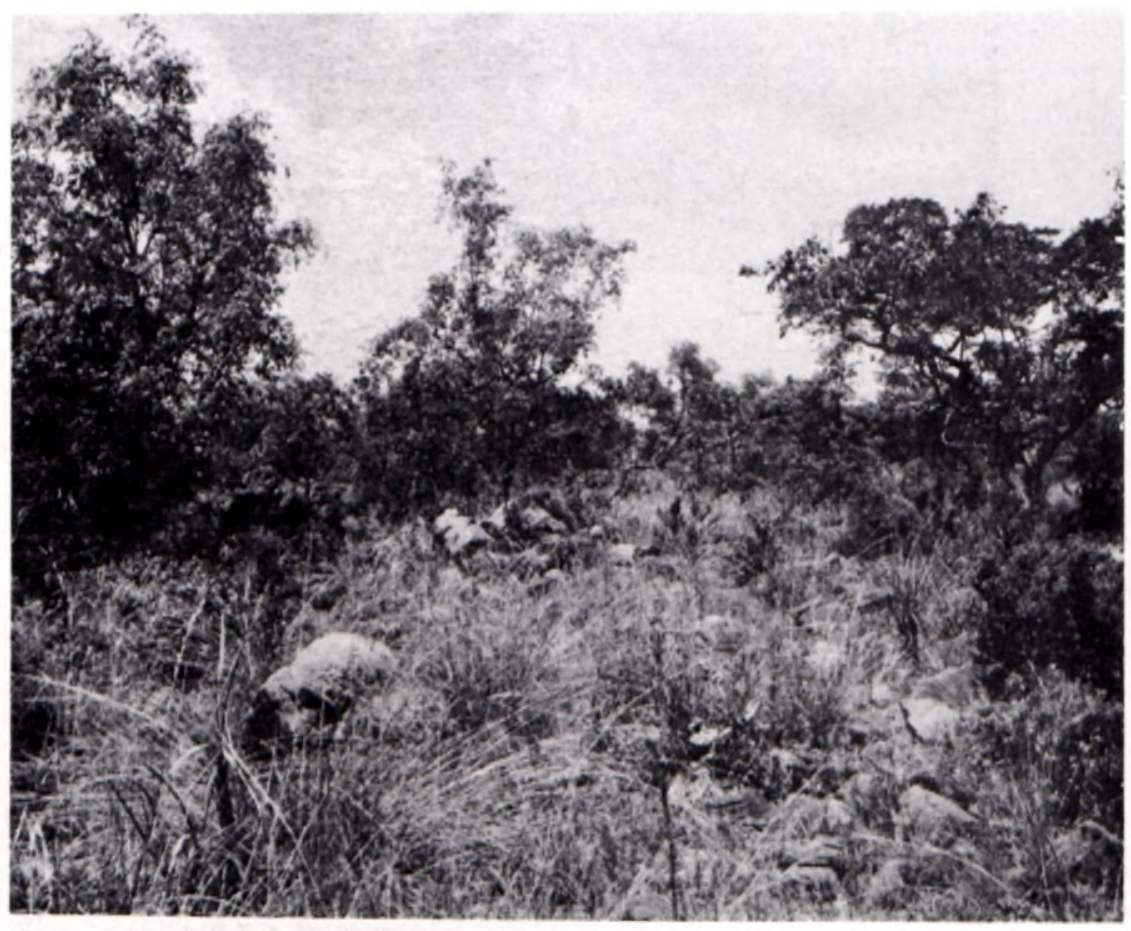

FIG. 11.-Barleria bremekampiiDiplorhynchus Tree Savanna of sandstone outcrop on Stemmerskop. 


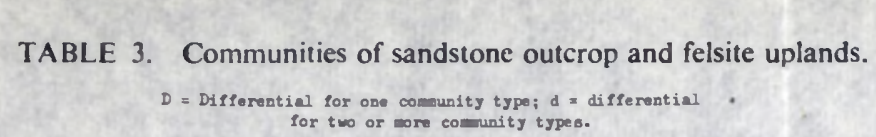

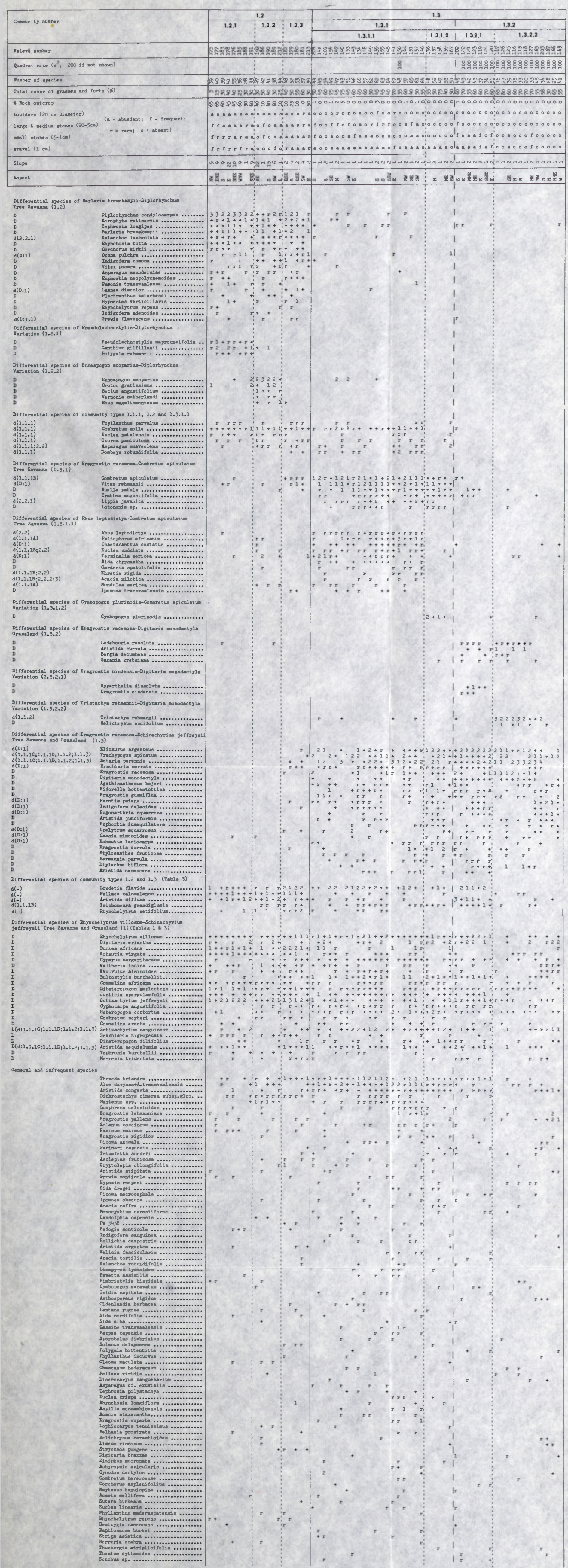

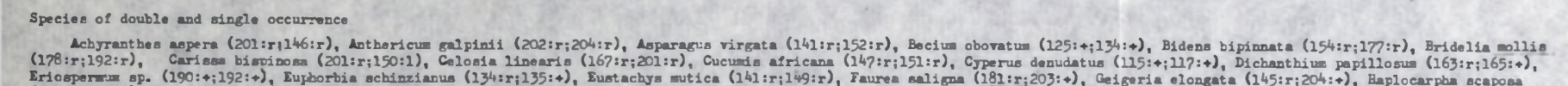

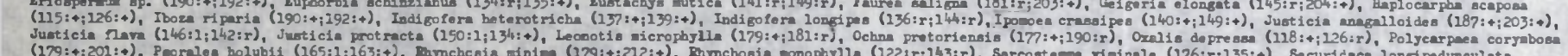

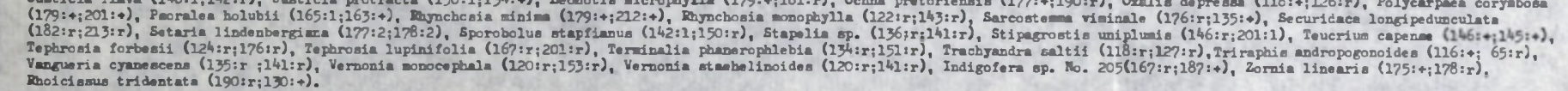

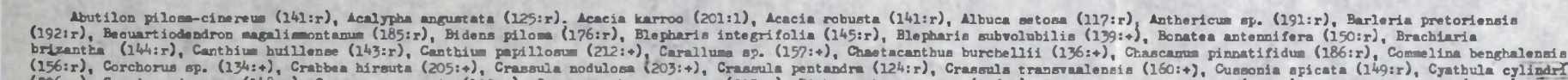

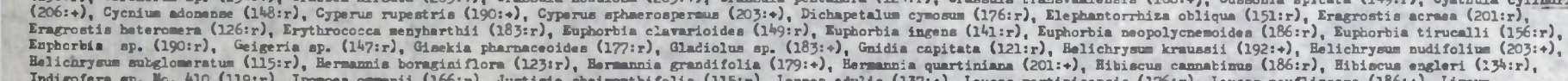

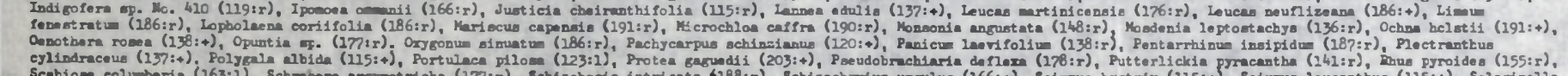

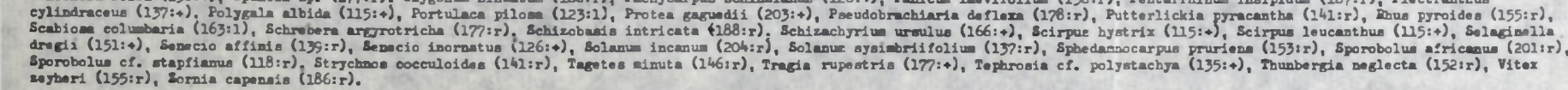


forbs have $50-60 \%$ cover - the highest in the community. Burkea africana and Diplorhynchus condylocarpon are the dominant trees and Loudetia flavida and Schizachyrium jeffreysii the dominant grasses.

Species which differentiate the community variation on their characteristically high cover are Burkea africana, Brachiaria serrata, Loudetia flavida and Merremia tridentata.

\subsection{Eragrostis racemosa-Schizachyrium jeffreysii} Tree Savanna and Grassland (Table 3).

This community includes all the felsite elevations and the footslopes of the southern sandstone areas and covers approximately a third of the Reserve. The topography is gently sloping to virtually level and during winter nights frost intensity presumably varies from mild on upper slopes to more severe on lower slopes. Because of their felsite origin and lower slope position the sandy soils are richer in minerals than soils of related communities on sandstone (1.1 and 1.2)

Broad-leaved savanna occurs on the uplands, where shallow, well-drained soils are underlain by weathered felsite. Grasslands occur on frostier lower slopes with shallow to deep poorly drained soils, underlain by a hard flintite bank. Most of the deeper grassland soils have mottled perched gley horizons and soft plinthic B-horizons, a result of fluctuating water tables and lateral movement of water. The termitaria thickets that occur throughout these savannas and grasslands belong to a different community (2.2).

Differential species include 14 grasses and eight forbs. Table 3 shows that the most common differential grasses, Elionurus argenteus, Trachypogon spicatus, Setaria perennis and Brachiaria serrata, are not exclusive to this community. Exclusive differential grasses are Eragrostis racemosa, E. gummiflua and Digitaria monodactyla. Constant differential forbs are Agathisanthemum bojeri, Nidorella hottentottica and Stylosanthes fruticosa.

Grunow (1965) described related savanna and grassland communities from Soutpan, near Pretoria. The distinctive habitat feature of the grassland there is soil drainage impeded by an ironpan near the soil surface. On the poorly drained felsite areas at Nylsvley frost appears to be an additional habitat factor favouring grasslands.

\subsubsection{Eragrostis racemosa-Combretum apiculatum} Tree Savanna.

Most of this savanna community on felsite occurs on the upper slopes of a broad ridge in the northwest and on a small isolated eastern elevation. Both stands occur uninterruptedly and coincide with soils of the Mispah Series (Mispah Form), which are shallow, well-drained and underlain by weathering felsite. Parts of the community occur on litholitic soil and on a local patch of soil belonging to the Glenrosa Series (Gemvale Form), which has a coarse to medium textured sandy orthic A-horizon and a cutanic B-horizon with $15-30 \%$ clay.

Tree density in the felsite savanna varies considerably. Open stands, with approximately $20 \%$ tree cover, are the most extensive. Trees become sparse with less than $5 \%$ cover towards the grasslands and dense tree stands with up to $60 \%$ cover occur in belts throughout the savanna region. These dense stands are presumably situated above interbedded rocks with favourable moisture conditions. This was suggested by Theron (1973) as a tentative explanation for the occurrence of similar dense belts in the felsite savannas at Loskopdam. Grass and forb cover in the savanna is usually between 40 and $70 \%$.

Combretum apiculatum and Vitex rehmannii are common trees in all three savanna phases and are also the most conspicuous differential species of the community. Other differential species include the low shrub Lippia javanica and the forbs Ruellia patula and Crabbea angustifolia.

The felsite savanna has a group of species in common with communities of sandstone uplands (1.1 and 1.2). The characteristic species combination, particularly that of the typical Rhus leptodictyaCombretum apiculatum Variation (1.3.1.1), shows affinities also with the Euclea undulata-Acacia tortilis Tree Savanna of the bottomlands (2.2). Theron (1973) found a highly significant positive regression of Combretum apiculatum, which is one of the differentiating species of the felsite savanna, with iron content of the soil. The closely related Andropogon amplectens-Combretum apiculatum-Bulbostylis collina Community described by Grunow (1965) occurs on very shallow, sandy, acid, sedentary soils, underlain by iron pan. A typical variation and a transitional variation to grassland were found.

\subsubsection{Rhus leptodictya-Combretum apiculatum Variation (Fig. 12)}

The extensive typical variation includes the moderately open to dense savannas, with $20-60 \%$ tree cover. Most trees fall in the $2-6 \mathrm{~m}$ height range and several species have individuals of various ages over the entire height range. The tallest trees, which are sparsely scattered, are usually up to $8 \mathrm{~m}$ and occasionally up to $10 \mathrm{~m}$ high

The typical variation has more than 20 woody species of which 17 occur in at least $25 \%$ of the relevés. The dominant woody species are Combretum apiculatum, Vitex rehmannii, Combretum molle, Peltophorum africanum, Terminalia sericea and Burkea africana. The dominant grasses are usually one or more of the following: Setaria perennis, Laudetia flavida, Themeda triandra, Trachypogon spicatus, Rhynchelytrum villosum, Schizachyrium sanguineum and Elionurus argenteus.

Nearly all differential species are woody and of these the following have high constancies: Rhus leptodictya, Peltophorum africanum, Euclea undulata and Terminalia sericea.

\subsubsection{Cymbopogon plurinodis-Combretum api- culatum Variation}

This variation, represented by 5 relevés, is transitional to Eragrostis racemosa-Digitaria monodactyla Grassland (1.3.2) on frosty lower slopes with poorly drained soils. Woody plants have less than $5 \%$ cover and include sparsely scattered tall trees, interspersed with small trees and shrubs that are predominantly between 1,5 and $4 \mathrm{~m}$ in height.

The transitional variation has much fewer constant woody species than the previous typical variation. Woody species occurring in more than one relevé are: Vitex rehmannii, with $100 \%$ presence; Combretum apiculatum $(80 \%$ presence); Acacia caffra $(60 \%)$; Combretum zeyheri $(40 \%)$; and Parinari capense, a low shrub in the field layer, with $40 \%$ presence. The dominant shrubs are usually either Vitex rehmannii or Acacia caffra. Dominant grasses include Elionurus argenteus, Digitaria cf. eriantha, Cymbopogon plurinodis, Trachypogon spicatus, Setaria perennis, Eragrostis curvula and Schizachyrium sanguineum. 
1.3.2 Eragrostis racemosa-Digitaria monodactyla Grassland

The grassland community of relatively frosty and poorly drained areas occurs on slopes at the bottom end of a broad valley in the northernmost part of the Reserve and as a narrow fringe on the lowest slopes of the sandstone and felsite areas (Fig. 13).

Cover in the grassland varies from $50-80 \%$. A short, xeric grassland variation occurs on very shallow dry soils of convex slopes and a tall mesic grassland variation occurs on deep soils of concave and flat areas where soil and moisture accumulate.

Although the community has few positive differential species, it is strongly negatively defined. The most constant differential species are the geophyte Ledebouria revoluta and the grass Aristida curvata.

\subsubsection{Eragrostis nindensis-Digitaria monodactyla} Variation

The xeric short grassland variation occupies most of the predominantly convex slopes in the northern part of the Reserve. The soils are shallow, gravelly and stony, usually dry but underlain by a hard impenetrable flintite bank causing impeded soil drainage during wet periods. Elionurus argenteus is the only constant dominant. Occasional co-dominants include Setaria perennis, Loudetia flavida, Rhynchelytrum villosum, Digitaria $\mathrm{cf}$. eriantha, Trachypogon spicatus, Brachiaria serrata and Aristida diffusa. In the xeric grasslands, besides numerous termitaria bush clumps, one also finds isolated tall trees or small groups of trees. These are mainly Combretum apiculatum, Acacia caffra, Peltophorum africanum and Burkea africana. Near alluvial areas intrusive shrubs of Acacia tortilis, A. nilotica and A. karroo may occur in the grasslands.

The community is differentiated by Hyperthelia dissoluta and by Eragrostis nindensis, a desiccation tolerant grass, typical of xeric grassland (cf. Gaff \& Ellis, 1974; and Coetzee, 1975).
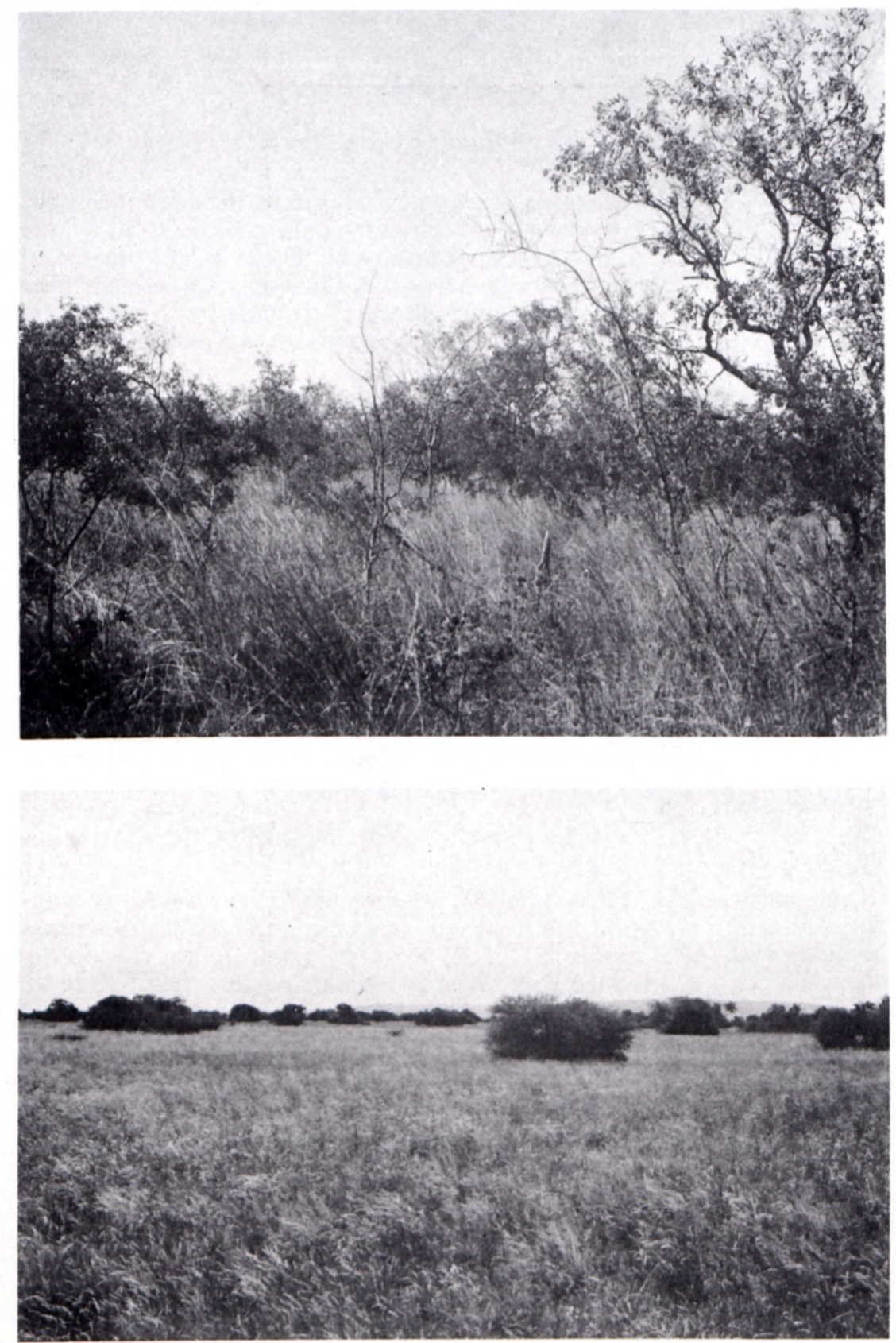

FIG. 12.-Rhus leptodictyaCombretum apiculatum Variation on felsite uplands.
FIg. 13.-Eragrostis racemosaDigitaria monodactyla Grassland with scattered termitaria thickets. 
1.3.2.2 Tristachya rehmannii-Digitaria monodactyla Variation

The mesic tall grassland variation occurs on deep, non-gravelly and moist soils found mainly on flat to concave, very gentle slopes in areas of soil and water accumulation. Included are parts of the felsite valley in the north and the grassland fringes on te lowest felsite and sandstone slopes. The deep grassland soils of the felsite region belong mainly to the Wasbank and Longlands Forms, which have orthic A-horizons; perched gley horizons, mottled with accumulated iron and magnesium oxides; and plinthic B-horizons - a type of profile resulting from prolonged poor drainage. The deep soils of the sandstone grassland belong mainly to the Fernwood Series (Fernwood Form) and Soetmelk Series (Avalon Form). The Fernwood Series is an orthic A-horizon on medium textured regic sand and the Soetmelk Series comprises an orthic A-horizon, yellow apedal B-horizon and a soft plinthic B-horizon with 15-35\% clay.

Tristachya rehmannii, a tall grass with very high fibre content, and Setaria perennis, a typical mesophytic grass (see also 1.1.2), are characteristically dominant. Occasional co-dominant and sub-dominants include Trachypogon spicatus, Elionurus argenteus, Digitaria cf. eriantha and Eragrostis gummiflua.

Differential species are Tristachya rehmannii (a dominant) and the mesophytic forb Helichrysum nudifolium.

2. Communities of flat bottomlands and of termitaria (excluding the self-mulching and vertic soils) (Table 4)

(Panicum maximum-Acacia tortilis Tree Savannas and Termitaria Thickets)

Part of the flat bottomlands consists of recent alluvium with a variety of calcareous clay soils. The vegetation is microphyllous thorn savanna. Included also are termitaria thickets which occur throughout the Reserve except on the sandstone elevations. Tree density varies from canopies interlocking on the termitaria to sparsely wooded grassland on very brackish clay soils. Trees vary in height up to $10 \mathrm{~m}$, the tallest trees occurring on termitaria. The field layer varies in height and cover depending on soil brackishness and the amount of grazing. Common differential species are Acacia tortilis in the tree and shrub layer; and Panicum maximum, Aloe spp. and Chloris virgata in the field layer.

Floristically related communities were described by Grunow (1965) from the farm Soutpan where Acacia tortilis is very common in communities on deep, well-drained, alkaline soils.

The savanna has two communities associated with differences in soil texture and soil brackishness.

\section{1 Sporobolus ioclados-Acacia tortilis Tree Savanna}

This community occurs on very heavy, compact, hard and brackish soils, belonging to the Shephardvale Series (Valsrivier Form; Fig. 14). The soils have a strongly structured B-horizon with more than $55 \%$ clay. All plots were heavily grazed and poor in species, the average number of species being 19 per plot. The vegetation usually consists of $2-6 \mathrm{~m}$ high trees, covering up to $10 \%$; a $0,5-2 \mathrm{~m}$ shrub layer with less than $1 \%$ cover; and a field layer up to $0,5 \mathrm{~m}$ with $15-50 \%$ cover.

The community is strongly differentiated by Sporobolus ioclados and Ocimum canum. The tree Boscia foetida var. rehmannii is also characteristic, but occurs sporadically.

\subsection{Euclea undulata-Acacia tortilis Tree Savanna and Termitaria Thickets}

This community includes the vegetation on less brackish, less heavy and less compact soils and on termitaria of the bottomlands. The vegetation varies from dense, impenetrable thicket on the termitaria to open savannas on alluvium. Carissa bispinosa and Euclea undulata are dominant and differential woody species. Two variations are recognized.

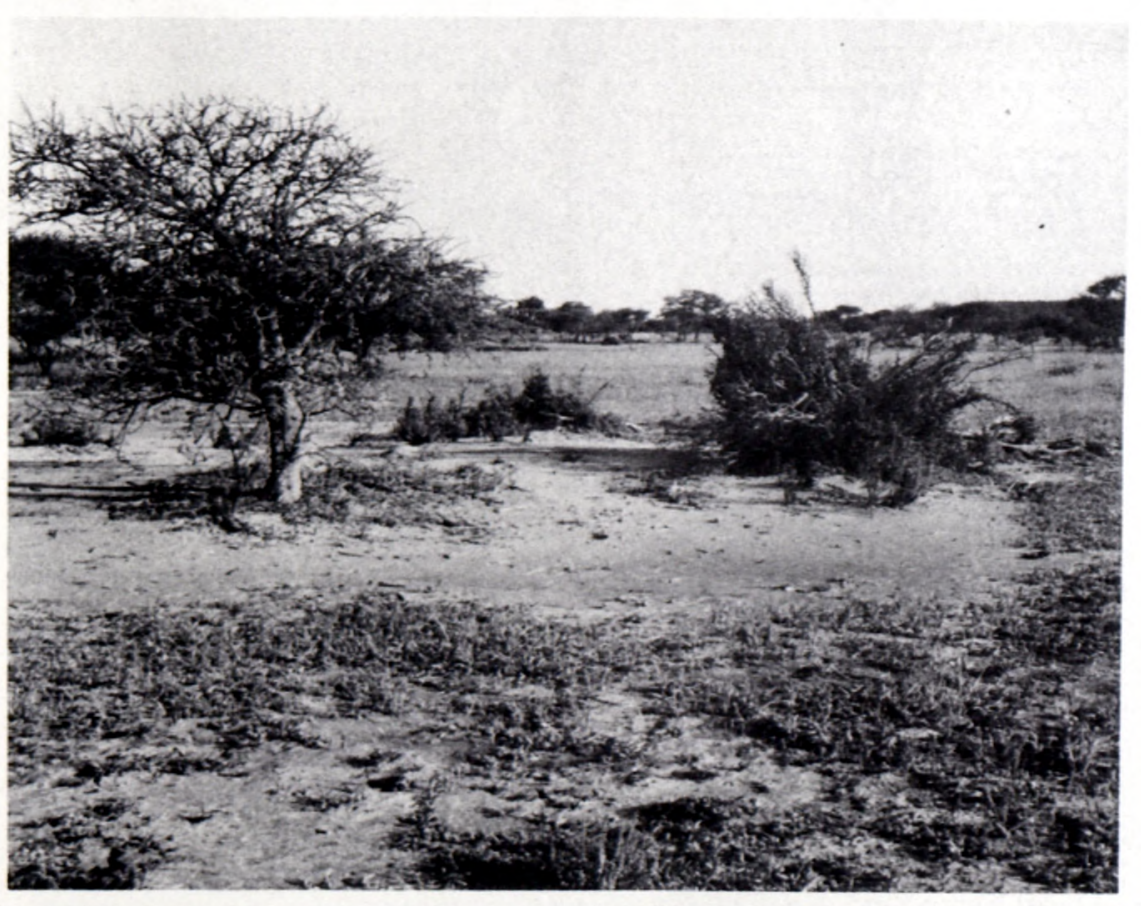

FIG. 14.-Sporobolus iocladosAcacia tortilis Tree Savanna on heavy brackish soils. Acacia tortilis in left foreground. 
TABLE 4. Communities of termitaria and alluvial flats.

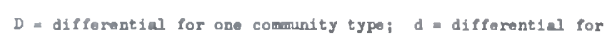
two or more comunity type.

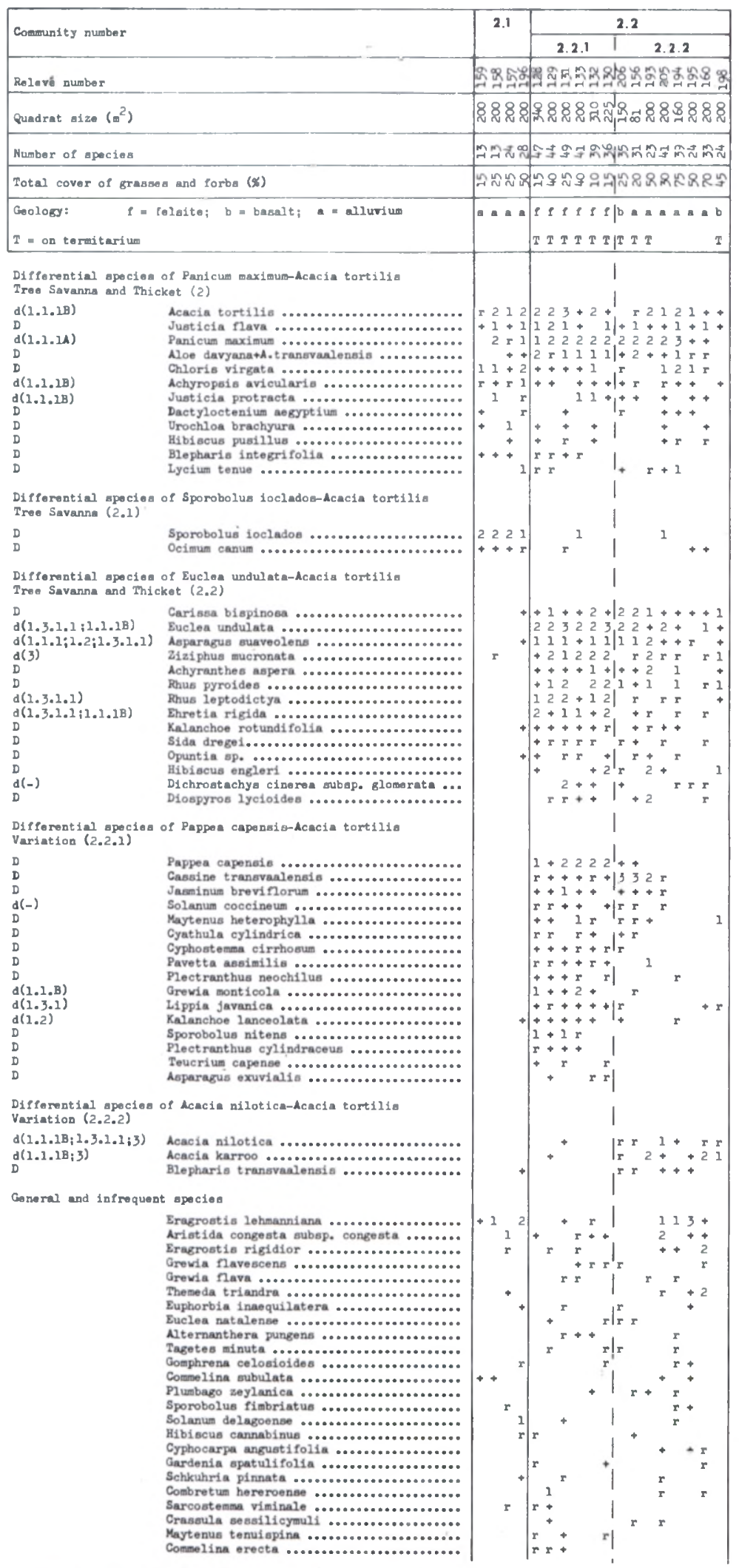

Species of double and aingle occurrence

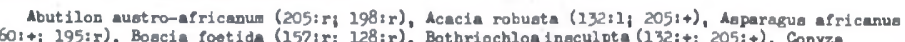

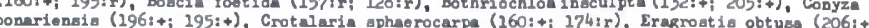

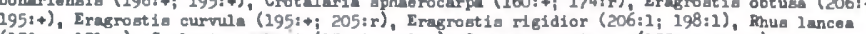
(130:r; 131:r), Scolopia zeyhert (230:2; 131:r), Securinega vi rose (133: $r ; 205:+)$, Tarchonanthue anphoratus (129: $+;$ 198:2), Vernonia poskeare (157: $r ; 194: r$ ).

Acacia hebeclada (128:2), Achyranthe a a cula (128:t), Acrotome anguatifolla (157:r), Artemiaiopais villosa (158:1), Asparague virgata (198: $r$ ), Bidens bipinnate (196: $r$ ), Bidens Dicliptera micrenthes (196:r), Dovyalis zeyheri (130:2), Echinochloa holubil (157:4), Ipaltes gariopina (159:1), Eragrostia ciliarensia (132: r), Eragroatia trichophora (15712), Erigeron noribundus (133ir), Jueticia natameneil a (160: $r$ ), Lepidium africanum (196: $r$ ), Loucas

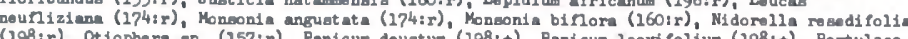
(198:r). Otiophera ap. (157:r). Panicum deuatum (198:t), Panicum lavifolium (198:t), Portulaca piloas (174:+), Thus gue inzil (206:*), Ruschin ap. (129:4), Beabiosa columbaria (198i+),

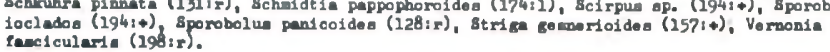




\subsubsection{Pappea capensis-Acacia tortilis Variation}

This variation comprises the vegetation on termitaria of the felsite elevations. There are many woody species. Plant growth is dense and sometimes virtually impenetrable because trees, shrubs and climbers interlock (Fig. 15).

A 2-8 $\mathrm{m}$ tree and tall shrub layer has $30-70 \%$ cover. Lower strata are: a 0,5-2 m shrub layer with $5-25 \%$ cover; and a field layer up to $0,5 \mathrm{~m}$ with 10 $40 \%$ cover. Euclea undulata and Ziziphus mucronata dominate the tree and tall shrub layer and Carissa bispinosa dominates the low shrub layer. The most common differential woody species is Pappea capensis. In the field layer Kalanchoe lanceolata, Plectranthus cylindraceus and $P$. neochilus are typical differentials.

\subsubsection{Acacia nilotica-Acacia tortilis Variation} (Fig. 16)

This variation occurs typically on calcareous alluvium. The relatively sandy soils on the river banks belong to the Limpopo Series (Oakleaf Form) and the heavier soils belong to the Shephardvale
Series (Valsrivier Form). Part of the variation is found on dark calcareous clay soils with vertic characters and crusting surface belonging to the Gelykvlakte Series (Arcadia Form).

Acacia tortilis is the dominant tree. Carissa bispinosa dominates the shrub layer, and Panicum maximum and Eragrostis lehmanniana dominate the field layer.

The vegetation consists of a $6-10 \mathrm{~m}$ tree layer with up to $10 \%$ cover; a $2-5 \mathrm{~m}$ tree layer with $1-5 \%$ cover; a 0,5-2 m shrub layer with $1-5 \%$ cover; and a 1,3 m high field layer with $20-75 \%$ cover, depending on the amount of grazing. Common differential species are Acacia nilotica, A. karroo and Blepharis transvaalensis.

Relevé Nos. 206, 156 and 193 are from bottomland termitaria and are transitional between the bottomland alluvium variation and the upland termitarium variation. Several differential species of the upland termitaria are present, including Cassine transvaalensis, Jasminum breviflorum and Maytenus heterophylla, but others such as Pavetta assimilis, Plectranthus neochilus and $P$. cylindraceus are absent. This illustrates a floristic gradient from elevated felsite

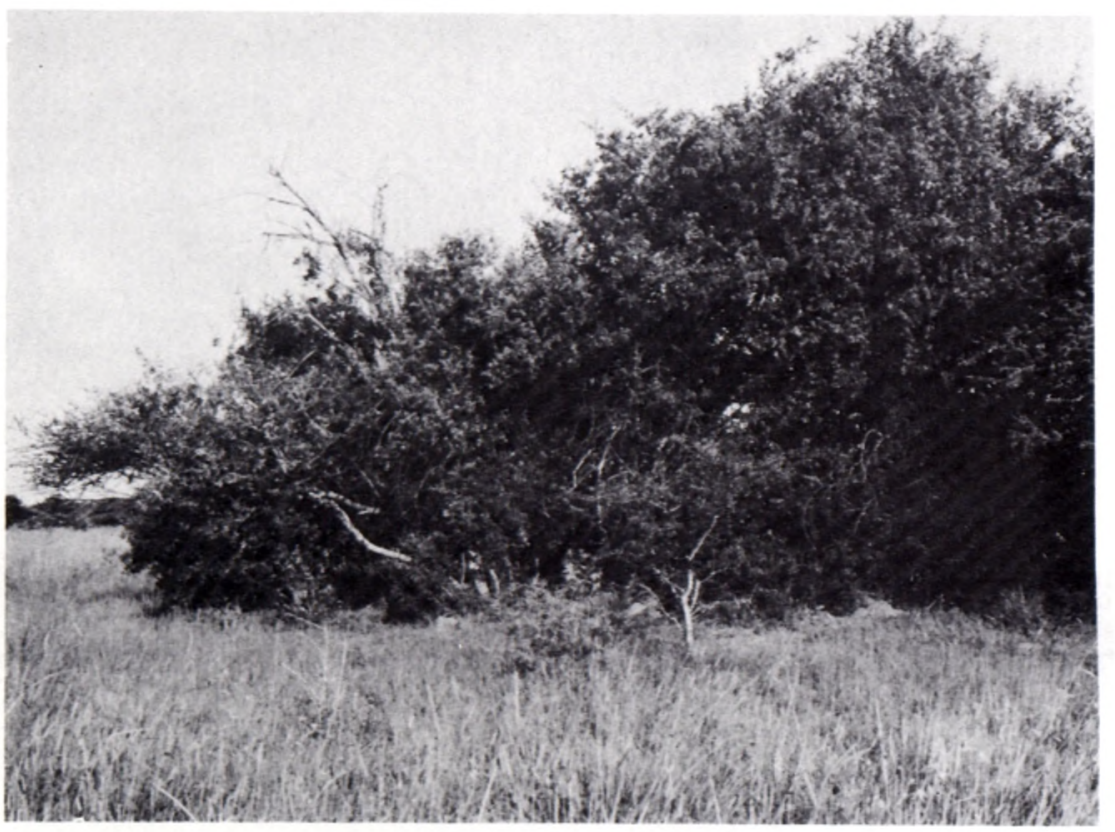

FIG. 15.-Termitarium thicket belonging to the Pappea capensis-Acacia tortilis Variation.

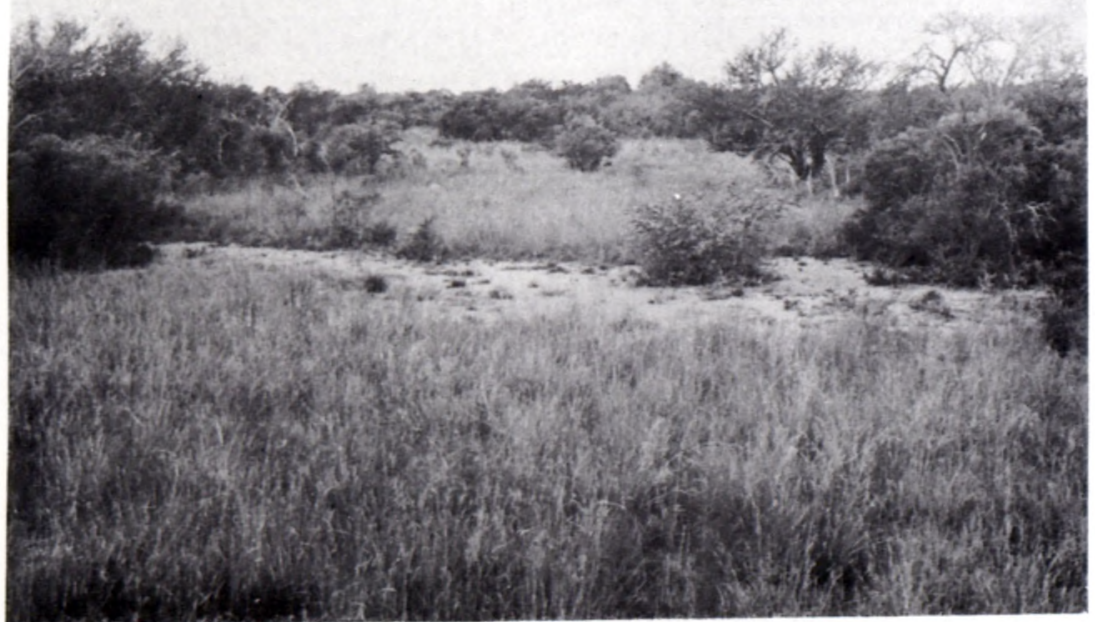

Fig. 16.-Acacia nilotica-Acacia tortilis Variation on alluvium. 
termitaria thicket $(2.2 .1)$, via bottomland termitaria thicket, to alluvium savanna (2.2.2). This gradient is associated with special termitarium conditions (Van der Schijff, 1957) and water table.

A separate alluvial community, of small extent, occurs south of the main road to Holme Park. The area is flat and low-lying with yellowish brown silty clay loam soil. The vegetation consists of a 2-3 m tall woody stratum with $2 \%$ cover, dominated by Rhus pyroides and Diospyros lycioides and a field layer with $75 \%$ cover, mainly of Elionurus argenteus and Eragrostis spp. Sparsely scattered tall Acacia mellifera subsp. detinens and Ziziphus mucronata trees and occasional small Acacia tortilis shrubs also occur. The woody species indicate relationships with other alluvial savannas but the field layer is distinctly different with elements of marshy grasslands and communities of self-mulching vertic soils. The following is an example of this Rhus pyroidesdominated savanna:

Relevé No. $216(10 \times 20 \mathrm{~m})$

Trees and shrubs:

Rhus pyroides.

Acacia tortilis.

Acacia mellifera subsp. detinens.

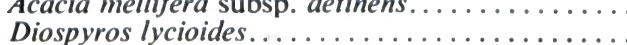

Field layer:

Denekia capensis.

Epaltes gariepina.

Bergia decumbens.

.

Panicum coloratum.

Eragrostis plana..

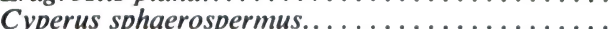

Setaria sphacelata.

Conyza bonariensis.

Verbena bonariensis.

Commelina africana..

Fimbristylis dichotoma.

Amphidoxa filaginea.

Nidorella resedifolia.
3. Communities of self-mulching vertic soils

(Aristida bipartita-Setaria woodii Tree Savanna and Grassland; Fig. 17)

The self-mulching vertic soil belt of the Arcadia Series (Arcadia Form) occurs in the south-eastern bottomland bordering the elevated sandstone area. Habitat features include a fluctuating water table, prolonged periods of inundation during heavy rainfall, swelling and contracting of the soil during wet and dry periods with considerable cracking when dry, a loose soil surface, a high calcium carbonate content in the soil and gilgai micro-relief.

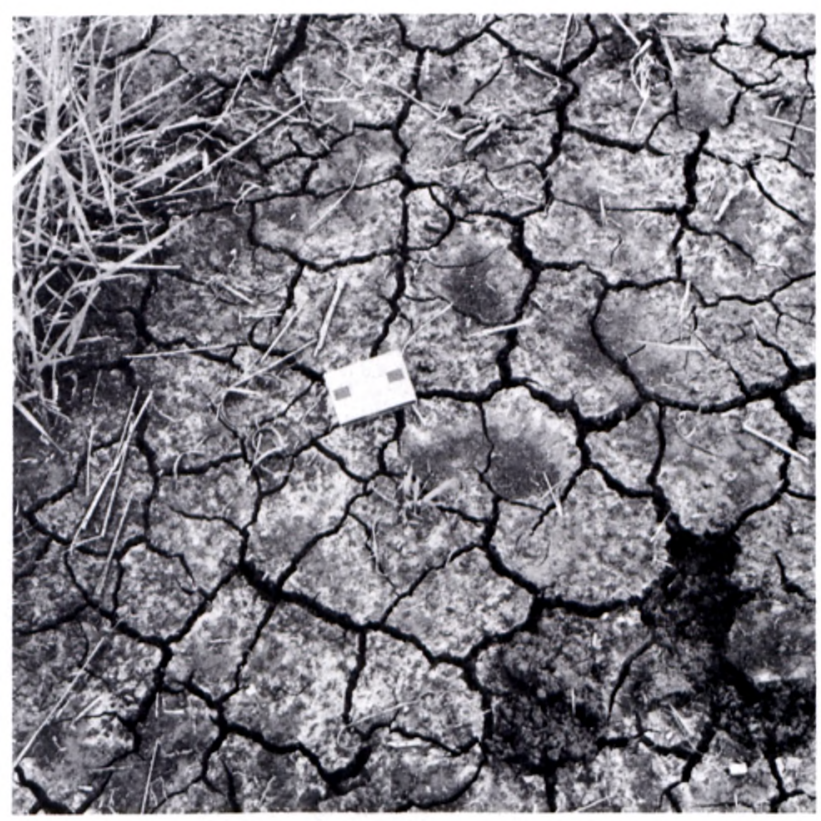

FIG. 17.-Vertic black clay soil of the Aristida bipartita-Setaria woodii Tree Savanna and Grassland.

TABLE 5. Communities of self-mulching, vertic clay.

$\mathrm{D}=$ Differential for one community type; $\mathrm{d}=$ differential for two or more community types.

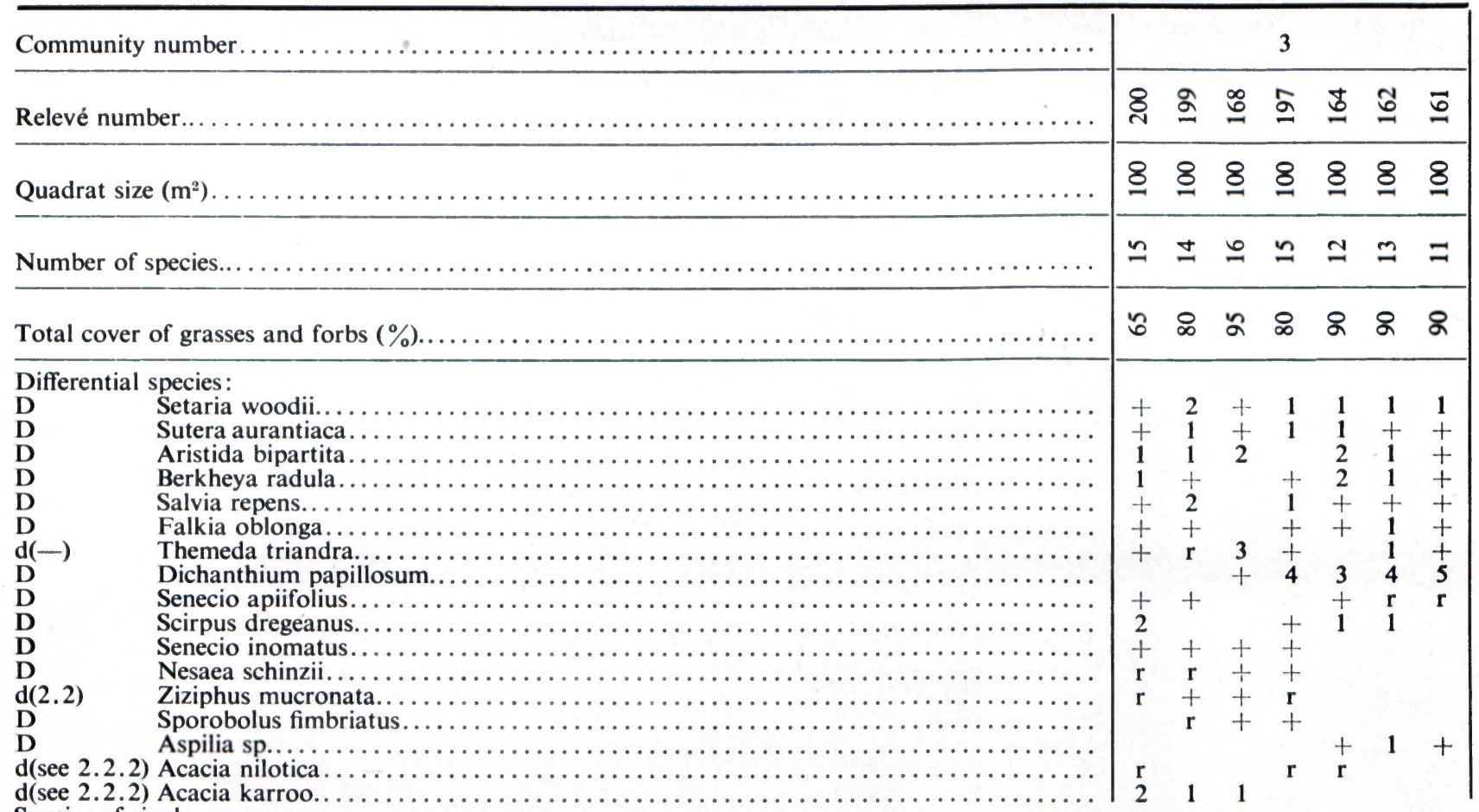

Species of single occurrence:

Acanthosicyos naudiniana (168: - ), Asparagus suaveolens (197:r), Celosia linearis (164:r), Epaltes gariepina (161: + ), Eragrostis heteromera (168:+), Mariscus sp. (162:+), Maytenus heterophylla (197:r), Nidorella resedifolia (199:r), Panicum natalense (168: + ), Psoralea holubii $(162:+)$, Rhus pyroides (200:r), Securidaca longipedunculata (168: + ), Tephrosia lupinifolia (168: + ), Wahlenbergia caledonica (168:r). 
The vegetation is mainly grassland but an open stand of thorn savanna occurs in the slightly higher north-western part where the water table is generally lower than in the grassland. Low termitaria mounds, several metres in diameter, also occur here. These better drained mounds have thickets belonging to the Acacia nilotica-Acacia tortilis Variation (2.2.2).

The field layer of the savanna phase corresponds to the grassland phase and this stratum has very few species in common with other communities in the Reserve. Grass and forb cover is between 80 and $90 \%$ and dominants include Setaria woodii, Dichanthium papillosum, Scirpus dregeanus and Aristida bipartita. The grass stratum is a mosaic of varying dominants coinciding with crests and troughs in the gilgai microrelief. Aristida bipartita is typically dominant on the relatively xeric crests. Tree cover in the savanna is between 1 and $5 \%$. The trees, mostly Acacia karroo, vary in height from small juveniles to $9 \mathrm{~m}$ tall. Ziziphus mucronata is the sub-dominant tree.

Trees have been cleared from part of the savanna area. Seedlings are common in parts of the grassland, but extend further into the grassland than from where the trees were cleared. We doubt that the occurrence of the seedlings indicates the potential range of the savanna, because the seedlings in the lower lying parts are probably periodically drowned. Interference with the water table level may, however, result in extensive savanna and thicket encroachment at the expense of pure grassland.

The two components in the field layer mosaic may be separately characterized as has, e.g., been done by Van Zinderen-Bakker \& Werger (1974) in the high altitude bogs of Lesotho and by Verster, De Villiers \& Scheepers (1973), in closely related gilgai vegetation on soils of the Arcadia Series, near Rustenburg. Verster et al. (1973) found that numerous species favoured either crests or troughs and that crests are floristically richer than troughs. In the present study each relevé covers both components. Until recently, part of the self-mulching vertic soils have been ploughed to produce fodder crops. The present secondary vegetation differs clearly from the surrounding grassland community The following is an example:

Relevé No. $215(10 \times 10 \mathrm{~m})$

Total cover of grasses and forbs: $60-65 \%$

\begin{tabular}{|c|}
\hline 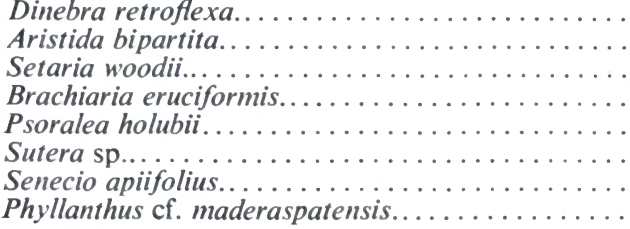 \\
\hline
\end{tabular}

\section{Communities of abandoned settlements (Table 6)}

On the elevated sandstone area, the disturbance effect on the vegetation around previous scattered native settlements can still be seen. The eutrophic Hutton soils here have a high phosphate content. The vegetation is differentiated by Eragrostis lehmanniana, which is the only dominant grass, sometimes with up to $80 \%$ cover and by Solanum delagoense and Crotolaria pisocarpa. Occasional tall Sclerocarya caffra trees around the settlements are characteristic.

The former differential activities of the tribes are still reflected in the present vegetation. Thorn trees, mainly Acacia tortilis, occur on housing and living sites where the soils are hard and compact (Fig. 18).

Sparsely wooded grassland dominated by Eragrostis lehmanniana occurs on the looser soils where agriculture must have been practised.

The thorn tree vegetation consists of a 2-6 m tree layer with up to $10 \%$ cover; a $0,5-2 \mathrm{~m}$ shrub layer with up to $5 \%$ cover; and a field layer up to $0,8 \mathrm{~m}$ high with $25-95 \%$ cover. Schkuhria pinnata, Leucas neuflizeana and Eragrostis rigidior are typical species in the field layer.

The grasslands have $0,5-3 \mathrm{~m}$ high scattered trees and shrubs, mainly Burkea africana and Terminalia sericea; and a field layer of up to $0,5 \mathrm{~m}$ with $40-80 \%$ cover. Cassia absus, Stipagrostis uniplumis, Eragrostis superba, Corchorus asplenifolia and Aristida stipitata are typical field layer species.

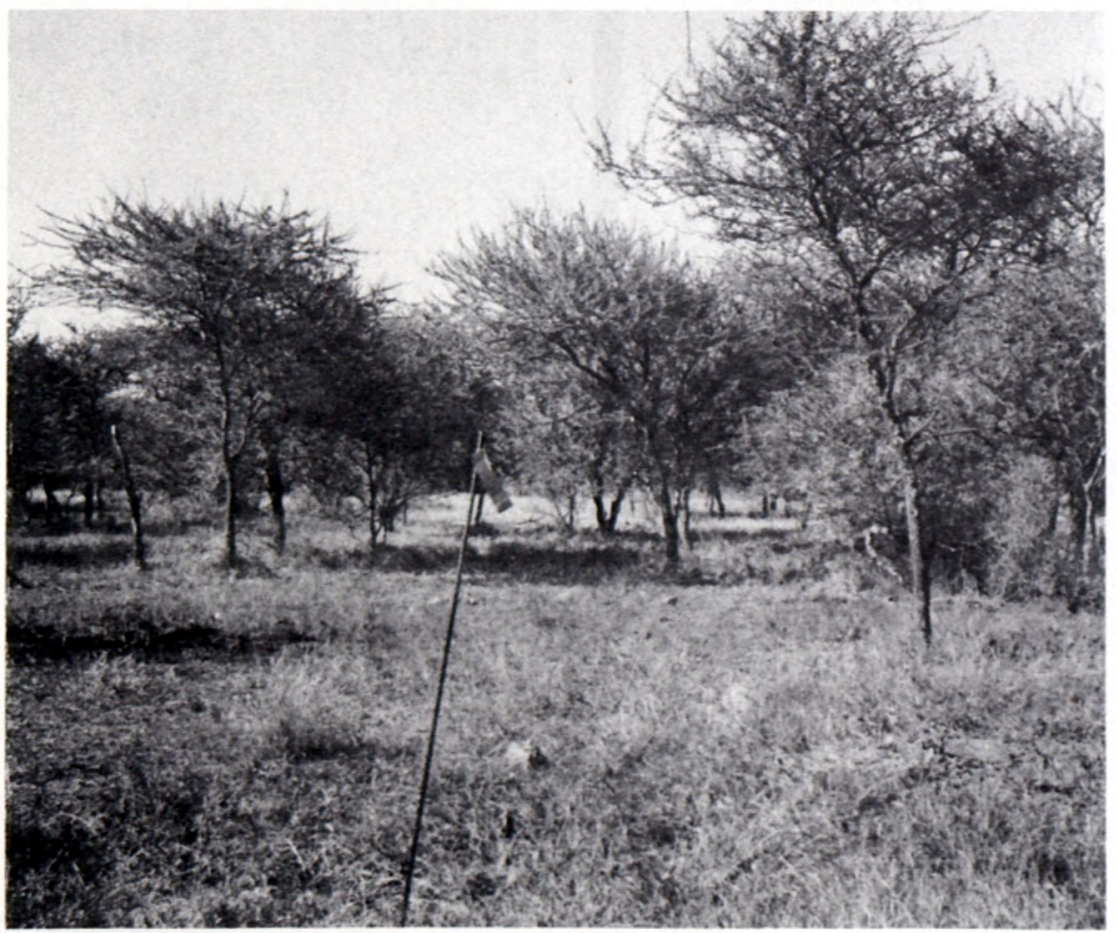

FIG. 18.-Acacia nilotica and Acacia tortilis trees on abandoned settlement. 
TABLE 6. Secondary communities.

$D=$ Differential for one community type; $d=$ differential for

two or more community types.

\begin{tabular}{|c|c|c|}
\hline Community number & 4.1 & 4.2 \\
\hline Relevé number & ल8 & 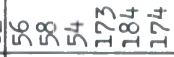 \\
\hline Quadrat size $\left(\mathrm{m}^{2}\right)$ & 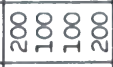 & 8. \\
\hline Number of species & 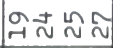 & 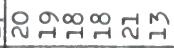 \\
\hline Total cover of grasses and forbs $(\%)$ & 8 ㄴํㄴำ워 & 읏 ผูก๊ำ \\
\hline
\end{tabular}

Differential species

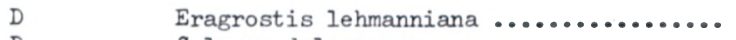

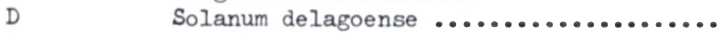

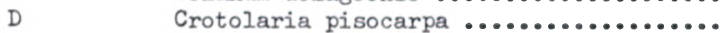

Differential species of Variation 4.1

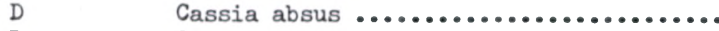

Stipagrostis uniplumis ..................

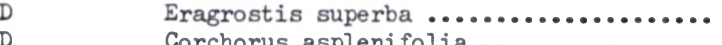

Corchorus asplenifolia .................

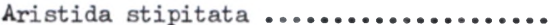

Differential species of Variation 4.2

Leucas neufliziana

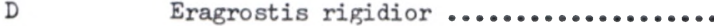

D Cynodon dactylon $\ldots \ldots \ldots \ldots \ldots \ldots \ldots \ldots \ldots . . . . . . .$.

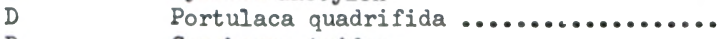

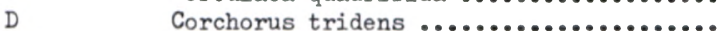

Species common to primary and secondary community types

$\mathrm{d}(1.1)$

d(I)

d(I)

$\mathrm{d}(1)$

d(I)

d(I)

d(1.1.1A;2)

d(1.1)

d(1.1)

d(1.1)

d(1.1)

d(I)

$\mathrm{d}(1)$

$\mathrm{d}(\mathrm{I})$

d(1.1)

d(I)

$\mathrm{d}(1)$

Vernonia poskeana

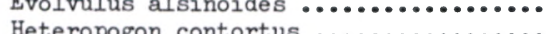

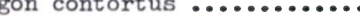

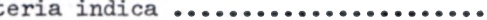

Tephrosia burchellii ..................

Digitaria eriantha .....................

Panicum maximum $\ldots \ldots \ldots \ldots \ldots \ldots \ldots \ldots \ldots$

Borreria scabra ......................

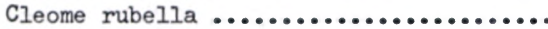

Limeum viscosum..$\ldots \ldots \ldots \ldots \ldots \ldots \ldots \ldots \ldots \ldots$

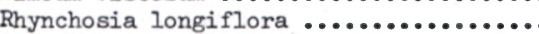

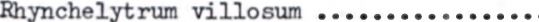

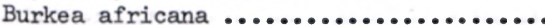

Terminalia sericea ....................

Striga asiatica..$\ldots \ldots \ldots \ldots \ldots \ldots \ldots \ldots \ldots$

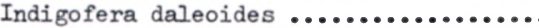

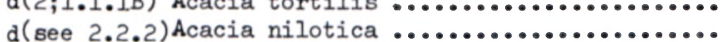
$\mathrm{d}(1.1)$

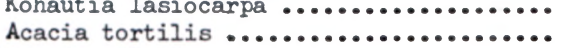

General and infrequent species

Aristida congesta ....................

Dichrostachys cinerea subsp. glomerata.

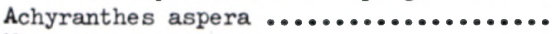

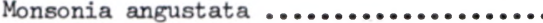

Sesamum olatum

12313325223

$+r$ r $212+12$

$1+++++$

$+1+$

$1+$

$r \quad \begin{aligned} & r+r+t r \\ & 32++t\end{aligned}$

$1+r+$

$+21$

1
$r$

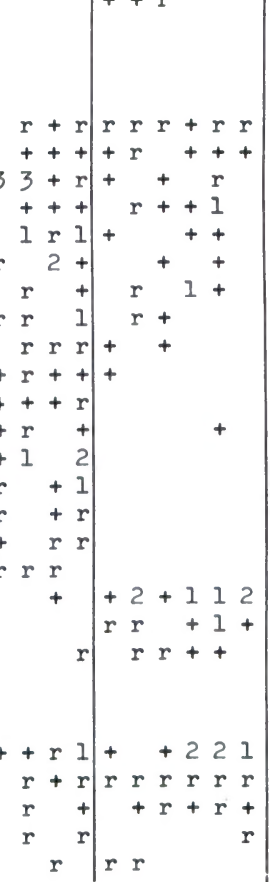

Species of double and single occurrence

Acacia karroo (31:r; 173:r), Aristida adscensionis (32:1; 173:+),

Chloris virgata $(32:+; 174:+)$, Crotolaria sphaerocarpa (174:r; 184:r), Enneapogon scoparius (32:+; $33: r)$, Indigofera macra $(22: r ; 31: r)$,

Pollichia campestris (173: $r ; 184: r$ ), Schmidtia pappophoroides (173:+;

$174: 1)$, Senecio apiifolius (32:r; 33:+), Sida alba (173:+; 184:r).

Abutilon austro-africanum $(184: r)$, Acacia caffra $(34: r)$,

Alternanthera pungens $(32: 2)$, Amaranthus thunbergii $(32: r)$, Aristida canescens ( $32: r)$, Asparagus plumosus ( $32: r)$, Asparagus suaveolens (173:r), Bidens pilosa (184:+), Blepharis integrifolia (184:+), Cenchrus ciliaris $(32:+)$, Chaetacanthus costatus $(184: r)$, Chenopodium carinatum $(32:+)$, Cleome monophylla $(31: r)$, Convolvulus sagittatus $(22:+)$, Cymbopogon excavatus (22:2), Dichapetalum cymosum (173:r), Dicoma macrocephala (184:r), Euphorbia inaequilatera $(22: r)$, Euphorbia tirucalli $(173:+)$, Felicia fascicularis $(184: 1)$, Felicia mossamedensis $(33:+)$, Gazania krebsiana (22:r), Gomphrena celosioides (173:+), Helichrysum argyrosphaerum $(32:+)$, Hibiscus cannabinus $(174:+)$, Hibiscus engleri $(173:+)$, Hibiscus trionum $(32: r)$, Indigofera rhytidocarpa $(30: r)$, Justicia flava ( $184:+)$, Melhania transvaalensis (33:r), Orthanthera jasminiflora $(33: r)$, Panicum natalense $(173:+)$, Polygala hottentotta (22:r), Portulaca pilosa (174:+), Rhynchosia confusa (22:r),

Rhynchelytrum repens (22:+), Sclerocarya caffra (184:1), Talinum caffrum $(30: r)$, Urochloa brachyura $(32:+)$, Zinnia multiflora $(33: r)$, Zornia capensis $(173:+)$. 
Many species occurring in this secondary vegetation indicate relationships with the less disturbed surrounding vegetation.

\section{PHYSIOGNOMIC SYNOPSIS AND GENERAL REMARKS}

The major physiognomic, dominance and physiographic types in the Reserve correspond well with floristically defined communities and can readily be delineated in the field and on aerial photographs in a precursory survey (Fig. 19).

1. Broad-leaved savannas are restricted to elevated areas. Together with upland grasslands they form one broad, floristically defined community associated with sandy soils. The major floristic sub-divisions of the community correspond to:

1.1 broad-leaved savanna on well drained, non litholitic sandstone soils (Burkea-TerminaliaOchna-Grewia dominated savanna);

1.2 broad-leaved savanna on litholitic sandstone soils (Diplorhynchus, or Burkea-Diplorhynchus, or Combretum molle-Croton gratissimus dominated savannas);

1.3 broad-leaved savannas on felsite [Combretum apiculatum-Vitex dominated savanna (1.3.1)]; and grassland on sandy soil [ grassland dominated by one or more of the following: Elionurus argenteus, Setaria perennis, Loudetia flavida, Rhynchelytrum villosum, Trachypogon spicatus, Brachiaria serrata, Aristida diffusa and Tristachya rehmannii (1.3.2)].

2. Microphyllous thorn savannas on bottomland alluvium and thickets on termitaria form another broad floristically defined community, with subdivisions corresponding to:

2.1 sparsely wooded grassland on compact, very brackish soils, with a field layer dominated by Sporobolus ioclados;

2.2 thickets on well drained upland termitaria (2.2.1); thickets on poorly drained bottomland termitaria (2.2.2) and thorn savanna on relatively loose alluvial soils, with a field layer dominated by Panicum maximum and Eragrostis lehmanniana.

3. Grassland and microphyllous thorn savanna of self-mulching vertic soils form a broad community which is divided into thorn savanna of the better drained parts, and grassland dominated by Setaria woodii, Dichanthium papillosum, Scirpus dregeanus and Aristida bipartita on the poorer drained parts.

4. Secondary grasslands and thorn savannas occur on abandoned lands and settlements.

The major physiognomic vegetation characters that change in relation to floristically defined communities are presence, cover and leaf or leaflet size of trees and shrubs. Leaf or leaflet size is strongly coupled with the presence or absence of thorns. The full floristic analysis showed the total floristic composition, characteristic species, floristic interrelationships, hierarchical level, variability and finer sub-divisions of the various community types and the phytosociological, ecological and geographical distribution of each species recorded in the survey.

The vegetation differences correspond well with differences in soil forms, series and phases. Important soil differences that are related to physiognomic and floristic vegetation differences are texture, depth, drainage and nutrient status as determined by geological origin, topographic position and disturbance.

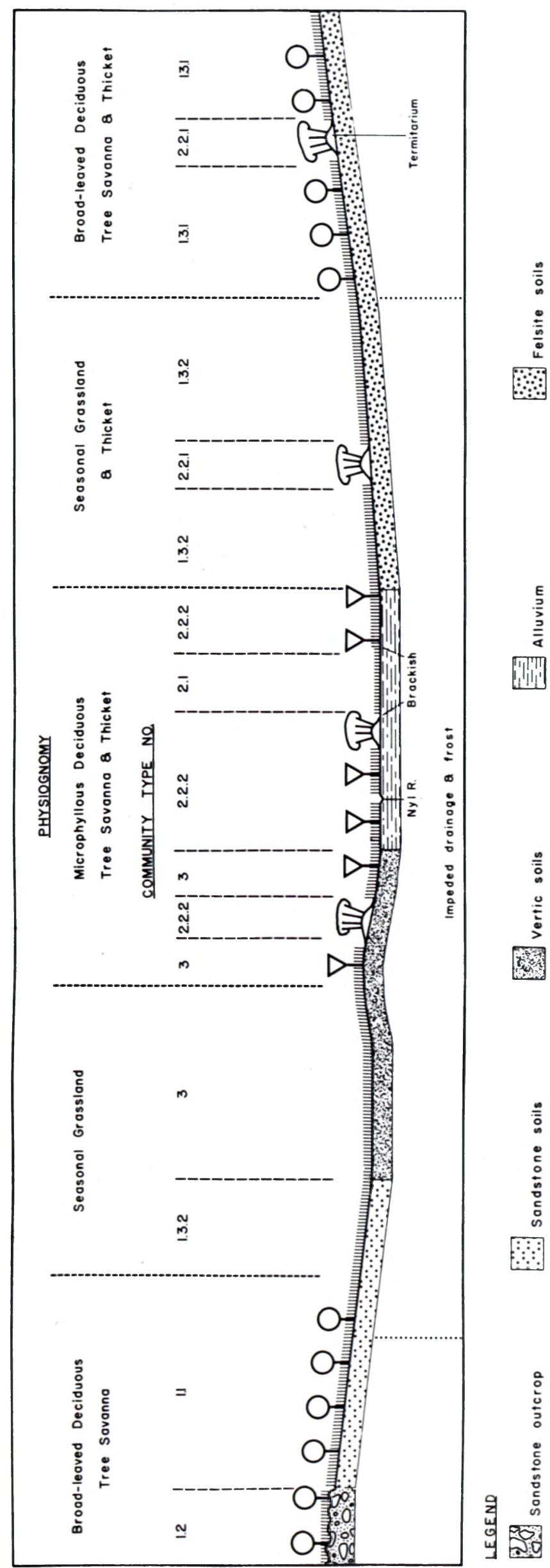


Frequency and severity of frost, which are correlated with topographic features and thus with soil differences, may also be an important determining factor.

\section{ACKNOWLEDGEMENTS}

Mrs I. C. van der Meulen greatly assisted us during the earlier phases of the project. Dr J.W. Morris helped with the computer printing of tables, which were then typed by Mrs J. M. Mulvenna. Mrs L. Williams gave technical assistance and our colleagues in the herbarium named numerous plant specimens. Prof. H. J. von $\mathrm{M}$. Harmse and Mr P. J. Botha provided information on the soils. These contributions, as well as valuable comments particularly by Dr D. Edwards and also by Messrs H. C. Taylor, E. A. Galpin, K. Hoffman, M. C. Rutherford and J. C. Scheepers, are gratefully acknowledged.

\section{UITTREKSEL}

Die plantegroei van die $\mathrm{Nylsvley-natuurreservat} \mathrm{in}$ die Transvaalse Gemengde Bosveld is hiërargies geklassifiseer met behulp van die Braun-Blanquet Metode. Die plantegroei is seisoenale grasveld en bladwisselende savanne met vier floristies-gedefinieerde hoofgroepe plantegemeenskappe:

(1) grasveld en breëblaar savannes op suur sanderige gronde van hoogliggende sandsteen en felsietgebiede;

(2) mikrofiele doringboomsavannes op kalkryke kleierige alluviale gronde van 'n laagte en digte termitaria-boskolle;

(3) grasveld en doringboomsavanne op kalkryke selfkrummelende vertiese grond; en

(4) sekondêre plantgemeenskappe op vroeëre Bantoenedersettings en onlangs geploegde grond.

Sewe primêre gemeenskappe met 12 variasies en 4 subvariasies, en drie sekondêre gemeenskappe word op basis van 216 relevés beskryf. 'n Ekosisteemstudiegebied is in meer detail as die res van die Reservaat bemonster en beskryf.

\section{REFERENCES}

Acocks, J. P. H., 1953. Veld Types of South Africa. Mem. Bot. Surv. S. Afr. 28:1-192.

AYENSU, E. S., 1973. Biological and morphological aspects of the Velloziaceae. Biotropica 5: 135-149.

Coetzee, B. J., 1974. A phytosociological classification of the vegetation of the Jack Scott Nature Reserve. Borhalia 11: 329-347.
Coetzee, B. J., 1975. A phytosociological classification of the Rustenburg Nature Reserve. Bothalia 1 1, 4: 561-580

Du Plessis, J. C., 1972. 'n Floristies-ekologiese studie van die plaas Doornkop in die distrik Middelburg, Transvaal. M.Sc. thesis, Univ. Pretoria.

EDWARDS, D., 1974. Conservation areas in relation to Veld Types. Koedoe: In preparation.

Galpin, E. E., 1926. Botanical survey of the Springbok Flats. Mem. Bot. Surv. S. Afr. 12:1-100.

Gaff, D. F. \& Ellis, R. P., 1974. South African grasses with foliage that revives after dehydration. Bothalia 11 : 305-308.

Grunow, J. O., 1965. Objective classification of plant communities: a synecological study in the Sour-mixed Bushveld of Transvaal. D.Sc. (Agric.) thesis, Univ. Pretoria.

Grunow, J. O., 1974. Savanna ecosystem research project: General information on Nylsvley farm. Unpubl.

RUTHERFORD, M. C., 1972. Notes on the flora and vegetation of the Omuverume Plateau-Mountain, Waterberg, South West Africa. Dinteria 8: 3-55.

SCHULZE, B. R., 1947. The climates of South Africa according to the classifactions of Köppen and Thornthwaite. $S$. Afr. Geogr. J. 29: 32-42.

Schulze, B. R., 1965. Climate of South Africa. 8. General survey. Pretoria: Govt. Printer \& Weather Bureau.

THERON, G. K., 1973. 'n Ekologiese studie van die plantegroei van die Loskopdamnatuurreservaat. D.Sc. thesis, Univ. Pretoria.

Trigonometrical Survey Office, 1967. South Africa 1:50000 sheer: 2428 DA Naboomspruit. Pretoria: Trig. Surv. Office.

VAN Der SCHIJf, H. P., 1957. 'n Ekologiese studie van die flora van die Nasionale Krugerwilduin. D.Sc. thesis, Univ. Potchefstroom.

Van Zinderen Bakker, E. M. \& Werger, M. J. A., 1974. Environment, vegetation and phytogeography of the highaltitude bogs of Lesotho. Vegeratio 29: 37-49.

Verster, E., De Villiers, J. M. \& Scheepers, J. C. 1973. Gilgai in the Rustenburg area. Agrochemophysica 4: 57-62.

Von M. Harmse, H. J. \& Botha, P. J. Report on the soils of Nylsvley Reserve. Pers. Comm.

WALTHER, H. \& LIETH, H., 1960. Klimadiagramm-Weltatlas. Jena: Fisher.

Weather Bureau, 1954. Climate of South Afrjca. 1. Climate Statistics. Pretoria: Govt. Printer \& Weather Bureau.

Weather Bureau, 1957. Climate of South Africa. 4. Rainfall maps. Pretoria: Govt. Printer \& Weather Bureau.

Weathfr Bureau, 1960. Climate of South Africa. 6. Surface winds. Pretoria: Govt. Printer \& Weather Bureau.

Weather Bureau, 1965. Climate of South Africa. 9. Average monthly rainfall up to the end of 1960. Pretoria: Govt. Printer \& Weather Bureau.

Werger, M. J. A., 1974a. On concepts and techniques applied in the Zürich-Montpellier method of vegetation survey. Bothalia 11: 309-323.

WERGER, M. J. A., 1974b. Applicability of Zürich-Montpellier Methods in Ärican and sub-tropical rangelands. In $R$. Tüxen (gen. ed.), Handbook of vegetation science: W. Krause (ed.), 13 Application to grassland husbandry. The Hague: Junk.

Westhoff, V. \& Van Der MaArel, E., 1973. The BraunBlanquet Approach. Tüxen, R. (gen. ed.), Handbook of vegctation science: Whittaker, R. F. (ed.) 6 Ordination and classification of vegetation. The Hague: Junk. 